\title{
OH reactivity at a rural site (Wangdu) in the North China Plain: contributions from $\mathrm{OH}$ reactants and experimental $\mathrm{OH}$ budget
}

\author{
Hendrik Fuchs ${ }^{1}$, Zhaofeng Tan ${ }^{2}, K_{\text {Keding Lu }}^{2}$, Birger Bohn ${ }^{1}$, Sebastian Broch ${ }^{1}$, Steven S. Brown $^{3}$, Huabin Dong $^{2}$, \\ Sebastian Gomm ${ }^{1, \mathrm{a}}$, Rolf Häseler ${ }^{1}$, Lingyan He ${ }^{4}$, Andreas Hofzumahaus ${ }^{1}$, Frank Holland ${ }^{1}$, Xin Li ${ }^{1, \mathrm{~b}}$, Ying Liu ${ }^{2}$, \\ Sihua Lu ${ }^{2}$, Kyung-Eun Min ${ }^{3,5, \mathrm{c}}$, Franz Rohrer ${ }^{1}$, Min Shao ${ }^{2}$, Baolin Wang ${ }^{2}$, Ming Wang ${ }^{6}$, Yusheng $\mathbf{W u}^{2}$, Limin Zeng ${ }^{2}$, \\ Yinson Zhang ${ }^{2}$, Andreas Wahner ${ }^{1}$, and Yuanhang Zhang ${ }^{2,7}$ \\ ${ }^{1}$ Institute of Energy and Climate Research, IEK-8: Troposphere, Forschungszentrum Jülich GmbH, Jülich, Germany \\ ${ }^{2}$ College of Environmental Sciences and Engineering, Peking University, Beijing, China \\ ${ }^{3}$ Chemical Sciences Division, Earth System Research Laboratory, National Oceanic and Atmospheric Administration, \\ Boulder, CO, USA \\ ${ }^{4}$ Key Laboratory for Urban Habitat Environmental Science and Technology, School of Environment and Energy, \\ Peking University Shenzhen Graduate School, Shenzhen, China \\ ${ }^{5}$ Cooperative Institute for Research in Environmental Sciences, University of Colorado, Boulder, CO, USA \\ ${ }^{6}$ School of Environmental Sciences and Engineering, Nanjing University of Information Science and Technology, \\ Nanjing, China \\ ${ }^{7}$ CAS Center for Excellence in Regional Atmospheric Environment, Chinese Academy of Science, Xiamen, China \\ anow at: d-fine GmbH, Opernplatz 2, 60313 Frankfurt, Germany \\ ${ }^{b}$ now at: College of Environmental Sciences and Engineering, Peking University, Beijing, China \\ ${ }^{c}$ now at: School of Environmental Science and Engineering, Gwangju Institute of Science and Technology, Gwangju, Korea
}

Correspondence to: Hendrik Fuchs (h.fuchs@fz-juelich.de) and Yuanhang Zhang (yhzhang@pku.edu.cn)

Received: 9 August 2016 - Published in Atmos. Chem. Phys. Discuss.: 10 August 2016

Revised: 24 November 2016 - Accepted: 6 December 2016 - Published: 13 January 2017

\begin{abstract}
In 2014, a large, comprehensive field campaign was conducted in the densely populated North China Plain. The measurement site was located in a botanic garden close to the small town Wangdu, without major industry but influenced by regional transportation of air pollution. The loss rate coefficient of atmospheric hydroxyl radicals $(\mathrm{OH})$ was quantified by direct measurements of the $\mathrm{OH}$ reactivity. Values ranged between 10 and $20 \mathrm{~s}^{-1}$ for most of the daytime. Highest values were reached in the late night with maximum values of around $40 \mathrm{~s}^{-1}$. OH reactants mainly originated from anthropogenic activities as indicated (1) by a good correlation between measured $\mathrm{OH}$ reactivity and carbon monoxide (linear correlation coefficient $R^{2}=0.33$ ) and (2) by a high contribution of nitrogen oxide species to the $\mathrm{OH}$ reactivity (up to $30 \%$ in the morning). Total $\mathrm{OH}$ reactivity was measured by a laser flash photolysis-laser-induced fluorescence instrument (LP-LIF). Measured values can be explained well by measured trace gas concentrations includ-
\end{abstract}

ing organic compounds, oxygenated organic compounds, $\mathrm{CO}$ and nitrogen oxides. Significant, unexplained $\mathrm{OH}$ reactivity was only observed during nights, when biomass burning of agricultural waste occurred on surrounding fields. $\mathrm{OH}$ reactivity measurements also allow investigating the chemical $\mathrm{OH}$ budget. During this campaign, the $\mathrm{OH}$ destruction rate calculated from measured $\mathrm{OH}$ reactivity and measured $\mathrm{OH}$ concentration was balanced by the sum of $\mathrm{OH}$ production from ozone and nitrous acid photolysis and $\mathrm{OH}$ regeneration from hydroperoxy radicals within the uncertainty of measurements. However, a tendency for higher $\mathrm{OH}$ destruction compared to $\mathrm{OH}$ production at lower concentrations of nitric oxide is also observed, consistent with previous findings in field campaigns in China. 


\section{Introduction}

Hydroxyl radicals $(\mathrm{OH})$ are the most important oxidizing agent for inorganic and organic pollutants in the atmosphere (Ehhalt, 1999). A large number of field campaigns have been conducted in the past to improve our understanding of radical chemistry in the atmosphere at various locations all over the world (Rohrer et al., 2014). However, only few have taken place in China, where air pollution is still a severe problem (Lu et al., 2010). Measurements during field campaigns in the Pearl River delta (PRD) and at a suburban location south of Beijing (Yufa) revealed a lack of understanding of radical chemistry by state-of-the-art chemical models, pointing to unknown $\mathrm{OH}$ radical sources (Hofzumahaus et al., 2009; Lu et al., 2012, 2013). Similar results were found at other locations, which were mainly dominated by biogenic emissions (Rohrer et al., 2014).

In summer 2014, the effort to improve our knowledge of radical chemistry in Chinese megacity areas was continued by a comprehensive field campaign at a location close to the city Wangdu in the North China Plain southwest of Beijing (Tan et al., 2017). A large set of instruments was deployed to detect radicals $\left(\mathrm{OH}, \mathrm{HO}_{2}, \mathrm{RO}_{2}\right)$, reactive trace gases (e.g., $\mathrm{CO}, \mathrm{NO}_{x}$, volatile organic compounds (VOCs)) and aerosol properties. Compared to our previous field campaigns in China in 2006 (Hofzumahaus et al., 2009), the quality and number of measurements have been improved. A large number of instruments measured a variety of different trace gases, part of which were simultaneously detected by several instruments. Specifically, measurements of organic oxygenated compounds such as formaldehyde and acetaldehyde were achieved, which was not the case in previous campaigns. Radical measurements were improved by performing additional tests of potential interferences in the detection of $\mathrm{OH}$, and a modified detection scheme for $\mathrm{HO}_{2}$ that avoids interference from $\mathrm{RO}_{2}$ was applied (Fuchs et al., 2011). Time series of radical measurements and a comparison with results from a chemical box model calculation are discussed in our accompanying paper by Tan et al. (2017).

$\mathrm{OH}$ reactivity $\left(k_{\mathrm{OH}}\right)$ is the pseudo first-order loss rate coefficient of $\mathrm{OH}$ radicals and represents the inverse chemical lifetime of $\mathrm{OH}$.

$k_{\mathrm{OH}}=\sum_{i} k_{\mathrm{OH}+X_{i}}\left[X_{i}\right]$

$X_{i}$ represents any $\mathrm{OH}$ reactant. Because of the large number of $\mathrm{OH}$ reactants in the atmosphere, it is of high value for the interpretation of radical chemistry to compare the direct measurement of $k_{\mathrm{OH}}$ with reactivities calculated from measured atmospheric $\mathrm{OH}$ reactant concentrations. The difference in measured and calculated reactivity is often referred to as missing reactivity.

Depending on the instrumentation that was available in field campaigns in the past, up to more than $70 \%$ of the measured reactivity was found to remain unexplained in different types of environments (e.g., cities, forests) (Yang et al., 2016). For our previous field campaigns in China, the measured $\mathrm{OH}$ reactivity was 2 times larger than the calculated $k_{\mathrm{OH}}$. The discrepancy could be quantitatively explained by the reactivity from oxygenated VOCs (OVOCs), which were not measured but estimated by a chemical model (Lou et al., 2010; Lu et al., 2013). In this campaign, the number of measured species was extended and included important atmospheric OVOCs, for example formaldehyde, acetaldehyde, isoprene oxidation products (methyl-vinyl ketone and methacrolein) and glyoxal.

Measurements of $\mathrm{OH}$ reactivity and $\mathrm{OH}$ concentrations can be combined to calculate the loss rate of $\mathrm{OH}$ radicals. This can then be compared to the sum of $\mathrm{OH}$ production rates from ozone and nitrous acid photolysis and the reaction of hydroperoxy radicals with nitric oxide and ozone as well as ozonolysis reactions of alkenes. All quantities that are required to do this calculation were measured in this campaign. This allows for a model-independent analysis of the chemical $\mathrm{OH}$ budget. This approach was successfully applied to quantify unaccounted $\mathrm{OH}$ production in our field campaigns in China in 2006 (Hofzumahaus et al., 2009).

In the following, we describe the technique for $\mathrm{OH}$ reactivity measurements applied in the campaign in Wangdu, discuss the time series of measurements, compare $\mathrm{OH}$ reactivity measurements with calculations from single reactant measurements and analyze the $\mathrm{OH}$ budget.

\section{Experimental setup}

The instruments, their setup at the field site and the measurement conditions are described in Tan et al. (2017). Therefore, only a brief description is given here.

\subsection{Measurement site}

Measurements took place inside a botanic garden close to the small town Wangdu in China between 7 June and 8 July 2014. Wangdu is located in the densely populated North China Plain but does not have major industry itself. Major cities are located mainly in the sector northeast to southwest of Wangdu, whereas there is a mountainous area with less industry northwest of Wangdu. The closest large city is Baoding, $35 \mathrm{~km}$ northeast of Wangdu. The measurement site had a distance of $2 \mathrm{~km}$ from a road with only local traffic. The botanic garden was surrounded by agricultural fields. Trace gases from local biogenic emissions of trees, bushes and from farming can be expected.

The site was chosen because it was not directly influenced by strong close-by anthropogenic emissions or the direct outflow of a big city. However, it was expected to observe regionally transported pollution in the North China Plain. 
Instruments were housed in seven shipping containers, which were partly stacked up so that inlets of instruments were at a height of $7 \mathrm{~m}$ above the ground.

\subsection{Instrumentation}

A large number of instruments characterized meteorological conditions, trace gas concentrations and aerosol properties. The measurements used for the $\mathrm{OH}$ reactivity analysis are listed in Table 1.

$\mathrm{OH}$ and $\mathrm{HO}_{2}$ radical concentrations were measured by a newly built instrument of Peking University (PKU) applying laser-induced fluorescence (PKU-LIF) (Tan et al., 2017). This instrument detects $\mathrm{OH}$ fluorescence by time-delayed single photon counting after excitation by short laser pulses at $308 \mathrm{~nm}$ in a low-pressure cell (Holland et al., 2003; Fuchs et al., 2011). $\mathrm{HO}_{2}$ radicals are detected as the sum of $\mathrm{OH}$ and $\mathrm{HO}_{2}\left(=\mathrm{HO}_{x}\right)$ after chemical conversion to $\mathrm{OH}$ in the reaction with nitric oxide (NO). In order to avoid significant simultaneous conversion of organic peroxy radicals $\left(\mathrm{RO}_{2}\right)$ (Fuchs et al., 2011), the amount of NO was adjusted to yield an $\mathrm{HO}_{2}$ conversion efficiency of only $6 \%$. The instrument sensitivity was calibrated every 3 to 4 days by a custom-built calibration source described in detail in Fuchs et al. (2011).

A commercial cavity ring-down instrument (Picarro model G2401) monitored $\mathrm{CO}, \mathrm{CH}_{4}$ and $\mathrm{H}_{2} \mathrm{O}$ concentrations. Concentration measurements of ozone by two commercial UV absorption instruments (Environment S.A. model 41M; Thermo Electron model 49i) agreed well within their accuracies during the campaign. Nitrogen oxides $\left(\mathrm{NO}\right.$ and $\left.\mathrm{NO}_{2}\right)$ were also detected by several instruments applying chemiluminescence (Thermo Electron model $42 \mathrm{i} \mathrm{NO}-\mathrm{NO}_{2}-\mathrm{NO}_{x}$ analyzer and Eco Physics model TR 780) that were equipped with a photolytic converter. Daily calibrations were performed using a certified gas standard. The field measurements differed on average by $20 \%$. Measurements of the Thermo Electron instruments appeared to be more precise and are used here (see Tan et al., 2017, for details). Because the reason for the disagreement could not be identified, the $20 \%$ difference adds to the uncertainty in NO measurements here.

Nitrous acid (HONO) concentrations were simultaneously measured by several instruments applying different measurement techniques (Tan et al., 2017). Custom-built instruments from FZJ (Forschungszentrum Jülich) (Li et al., 2014) and from PKU (Liu et al., 2016) utilized long-path absorption photometry (LOPAP). In addition, three custom-built instruments applied cavity-enhanced absorption spectroscopy (CEAS) for the detection of HONO. They were operated by the US National Oceanic and Atmospheric Administration (NOAA) (Min et al., 2016), by the Anhui Institute of Optics and Fine Mechanics (AIOFM), and by the University of Shanghai for Science and Technology (USST). A gas and aerosol collector (GAC), which is based on the wet denuder/ion chromatography technique, could also de- tect HONO (Dong et al., 2012). Only measurements by the two LOPAP instruments and the CEAS by NOAA resulted in good data coverage. The agreement between these instruments was diverse. Differences were often less than $30 \%$ but could be as high as a factor of 2 for certain periods (several hours). The reason for the disagreement during these times is not clear. For the purpose of the analysis here, measurements by the LOPAP instrument from Forschungszentrum Jülich are used (Li et al., 2014) because this instrument showed best data coverage and the lowest detection limit. This instrument was calibrated by using a liquid standard as described in $\mathrm{Li}$ et al. (2014) every 10 days. The choice of the HONO data set has a rather small impact on the calculated $\mathrm{OH}$ reactivity, as well as on the calculated total $\mathrm{OH}$ production rate, which was dominated by $\mathrm{OH}$ recycling from $\mathrm{HO}_{2}$ during the daytime (see below).

For the analysis of the $\mathrm{OH}$ reactivity, measurements of organic trace gases are essential. In total, 59 organic species $\left(\mathrm{C}_{2}-\mathrm{C}_{11}\right.$ alkanes, $\mathrm{C}_{2}-\mathrm{C}_{6}$ alkenes, $\mathrm{C}_{6}-\mathrm{C}_{10}$ aromatics and isoprene) were detected by a custom-built gaschromatography system equipped with a flame ionization detector (FID) (Wang et al., 2014). Full calibrations using certified gas standards (Air Environmental Inc., Spectra Gases Inc.) were done before and after the campaign. Drifts of the sensitivity during the campaign were accounted for by measuring the instrument sensitivity for bromochloromethane, 1,4-difluorobenzene, chlorobenzene and 1-bromo-3-fluorobenzene every second day. Formaldehyde (HCHO) was detected by a commercial Hantzsch monitor (Aerolaser model AL4021) and glyoxal (CHOCHO) by a custom-built cavity-enhanced spectrometer (Min et al., 2016). In addition, acetaldehyde and the sum of methyl vinyl ketone (MVK) and methacrolein (MACR) were measured by a commercial proton transfer reaction-mass spectrometry system (PTR-MS, Ionicon). Some of the species or family species were simultaneously detected by the gaschromatography (GC) system and the PTR-MS (isoprene, benzene, toluene, styrene, $\mathrm{C}_{8}$-aromatics, $\mathrm{C}_{9}$-aromatics). Measurements during the daytime agreed well within 30 to $50 \%$ (Tan et al., 2017). Calibration of the PTR-MS instrument was done every day using a certified gas standard (Air Environmental Inc.).

Photolysis frequencies were calculated from the spectral actinic photon flux density measured by a spectrometer that was calibrated against absolute irradiance standards (Bohn et al., 2008).

\subsection{OH reactivity measurements}

The $\mathrm{OH}$ reactivity instrument measures directly pseudo firstorder loss rate coefficients (Eq. 1) of $\mathrm{OH}$ in the ambient air. The measurement is based on artificial $\mathrm{OH}$ generation by pulsed laser flash photolysis (LP) of ozone in ambient air combined with the detection of the temporal $\mathrm{OH}$ decay by LIF. The method was initially developed for field appli- 
Table 1. Instruments deployed in the campaign and used for data analysis.

\begin{tabular}{|c|c|c|c|c|}
\hline & Measurement technique & Time resolution & $1 \sigma$ detection limit & $1 \sigma$ accuracy \\
\hline$k_{\mathrm{OH}}$ & LP-LIF ${ }^{\mathrm{a}}$ & $180 \mathrm{~s}$ & $0.3 \mathrm{~s}^{-1}$ & $\pm 10 \%+0.7 \mathrm{~s}^{-1}$ \\
\hline $\mathrm{OH}$ & $\mathrm{LIF}^{\mathrm{b}}$ & $32 \mathrm{~s}$ & $0.32 \times 10^{6} \mathrm{~cm}^{-3}$ & $\pm 11 \%$ \\
\hline $\mathrm{HO}_{2}$ & $\mathrm{LIF}^{\mathrm{b}}$ & $32 \mathrm{~s}$ & $0.10 \times 10^{8} \mathrm{~cm}^{-3}$ & $\pm 16 \%$ \\
\hline Photolysis frequency & spectroradiometer & $20 \mathrm{~s}$ & $\mathrm{c}$ & $\pm 10 \%$ \\
\hline $\mathrm{O}_{3}$ & UV photometry & $60 s$ & $0.5 \mathrm{ppbv}$ & $\pm 5 \%$ \\
\hline NO & chemiluminescence & $180 \mathrm{~s}$ & $60 \mathrm{pptv}$ & $\pm 20 \%$ \\
\hline $\mathrm{NO}_{2}$ & chemiluminescence $^{\mathrm{d}}$ & $600 \mathrm{~s}$ & $300 \mathrm{pptv}$ & $\pm 20 \%$ \\
\hline HONO & LOPAP & $300 \mathrm{~s}$ & 7 pptv & $\pm 20 \%$ \\
\hline $\mathrm{CO}, \mathrm{CH}_{4}, \mathrm{CO}_{2}, \mathrm{H}_{2} \mathrm{O}$ & cavity ring-down & $60 s$ & $\mathrm{f}$ & $\mathrm{g}$ \\
\hline $\mathrm{SO}_{2}$ & pulsed UV fluorescence & $60 s$ & $0.1 \mathrm{ppbv}$ & $\pm 5 \%$ \\
\hline $\mathrm{HCHO}$ & Hantzsch fluorimetry & $60 s$ & $25 \mathrm{pptv}$ & $\pm 5 \%$ \\
\hline Volatile organic compounds ${ }^{\mathrm{h}}$ & GC-FID/MS ${ }^{1}$ & $1 \mathrm{~h}$ & 20 to $300 \mathrm{pptv}$ & \pm 15 to $20 \%$ \\
\hline Volatile organic compounds ${ }^{\mathrm{i}}$ & PTR-MS & $20 s$ & $0.2 \mathrm{ppbv}$ & $\pm 15 \%$ \\
\hline Glyoxal & CEAS $^{j}$ & $1 \mathrm{~s}$ & $0.02 \mathrm{ppbv}$ & $\pm 5.8 \%$ \\
\hline
\end{tabular}

${ }^{a}$ Laser photolysis-laser-induced fluorescence. ${ }^{b}$ Laser-induced fluorescence. ${ }^{c}$ Process specific, 5 orders of magnitudes lower than maximum in noon time.

${ }^{\mathrm{d}}$ Photolytical conversion to NO before detection, home-built converter. ${ }^{\mathrm{e}}$ Long-path absorption photometry. ${ }^{\mathrm{f}}$ Species specific, for CO: 1 ppbv;

$\mathrm{CH}_{4}: 1$ ppbv; $\mathrm{CO}_{2}: 25$ ppbv; $\mathrm{H}_{2} \mathrm{O}: 0.1 \%$ (absolute water vapor content). ${ }^{\mathrm{g}}$ Species specific, for $\mathrm{CO}: 1 \mathrm{ppbv} ; \mathrm{CH}_{4}: \pm 1 \mathrm{ppbv} ; \mathrm{CO}_{2}: \pm 25$ ppbv; $\mathrm{H}_{2} \mathrm{O}: \pm 5 \%$.

${ }^{h}$ VOCs including $\mathrm{C}_{2}-\mathrm{C}_{11}$ alkanes, $\mathrm{C}_{2}-\mathrm{C}_{6}$ alkenes, $\mathrm{C}_{6}-\mathrm{C}_{10}$ aromatics. ${ }^{\mathrm{i}}$ OVOCs including acetaldehyde, methyl-vinyl ketone and methacrolein.

$\mathrm{j}$ Cavity-enhanced absorption spectroscopy.

cation by Sadanaga et al. (2004) and is applied today by several other groups (Lou et al., 2010; Parker et al., 2011; Stone et al., 2016). The instrument deployed in this campaign is similar to the instrument described in Lou et al. (2010), which was used for measurements in our two field campaigns in 2006 in China. Since then, a second instrument has been built specifically for the deployment on a Zeppelin NT airship (Li et al., 2014), but it can also be operated on the ground. This instrument was deployed. Figure 1 gives a schematic representation of the instrument without the pump (Edwards model XDS35i) needed for the operation of the low-pressure LIF cell and without the laser that provides the $308 \mathrm{~nm}$ radiation for the excitation of $\mathrm{OH}$. The $308 \mathrm{~nm}$ radiation is delivered by the dye laser system that is also used in the instrument for the $\mathrm{OH} \mathrm{HO}$ and $\mathrm{RO}_{2}$ concentration measurements described in Tan et al. (2017). This laser has three output fibers to provide laser light, one of which is used for the $\mathrm{OH}$ reactivity instrument.

The $k_{\mathrm{OH}}$ instrument is mounted in a $19^{\prime \prime}$ rack that was placed inside one of the upper shipping containers at the field site. The inlet line (outer diameter $10 \mathrm{~mm}$, length approximately $6 \mathrm{~m}$ ) was made of stainless steel that had a SilcoNert 2000 coating. Such a sampling line has been used for $\mathrm{OH}$ reactivity measurements in the Jülich atmosphere simulation chamber SAPHIR for many years without notable effects on measurements. Approximately $20 \mathrm{Lmin}^{-1}$ of ambient air is sampled through a flow tube made of anodized aluminium (length: $60 \mathrm{~cm}$; inner diameter: $4 \mathrm{~cm}$ ). Downstream of the flow tube, the flow rate is measured by a flowmeter and controlled by a blower.
The pressure inside the flow tube is $1 \mathrm{~atm}$, and the temperature was the same as in the field container (between 22 and $30^{\circ} \mathrm{C}$ ). Ambient temperature was higher with up to $38^{\circ} \mathrm{C}$ for some periods during the campaign. Differences in temperature and pressure potentially effect the measured reactivity due to changes in the reactant concentrations and in reaction rate constants (Lou et al., 2010). Measured reactivities were corrected for changes in the reactant concentration calculated from measured ambient and flow-tube temperature and pressure values (corrections were less than $2 \%$ ). Sensitivity studies taking either ambient temperature or flow-tube temperature for the calculation of $\mathrm{OH}$ reactivity from measured $\mathrm{OH}$ reactant concentrations (see below) indicate that the effect of temperature differences on reaction rate constants resulted in changes in the $\mathrm{OH}$ reactivity of typically less than $1 \%$ (maximum values $4 \%$ ) for conditions of this campaign.

High $\mathrm{OH}$ concentrations on the order of $10^{9} \mathrm{~cm}^{-3}$ are produced by flash photolysis of $\mathrm{O}_{3}$ at $266 \mathrm{~nm}$, with a subsequent reaction of $\mathrm{O}^{1} \mathrm{D}$ with water vapor. The $266 \mathrm{~nm}$ laser pulses (pulse energy 20 to $28 \mathrm{~mJ}$, repetition rate $1 \mathrm{~Hz}$, pulse duration less than $10 \mathrm{~ns}$ ) are provided by a compact, frequency quadrupled Nd:YAG laser (Quantel model Ultra 100). The laser is mounted on one side of an optical rail, on which the flow tube is mounted on the opposite side. The laser beam is widened by an optical telescope to a diameter of $3 \mathrm{~cm}$ and guided to the flow tube by two turning mirrors.

Water vapor, temperature and pressure in the flow tube are continuously monitored. Normally, ozone and water vapor concentrations in the sampled ambient air are sufficiently high in order to produce high $\mathrm{OH}$ concentrations. However, ozone can be depleted during night due to its reaction 


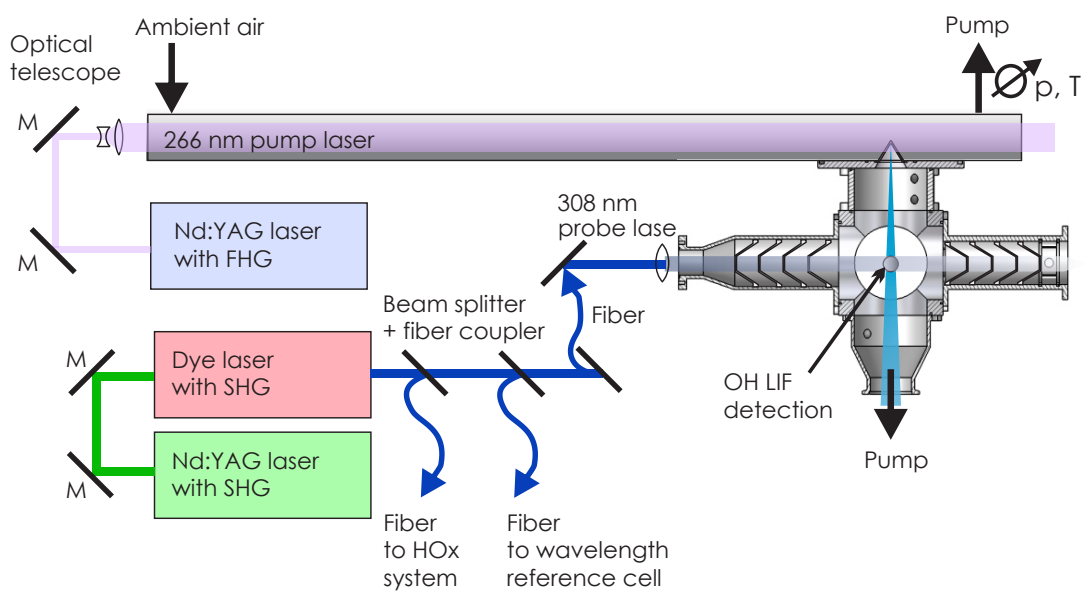

Figure 1. Schematics of the Jülich $\mathrm{OH}$ reactivity instrument (M: turning mirror). Ambient air is sampled into a flow tube. A small part of the air is drawn into the $\mathrm{OH}$ detection cell that is operated at a pressure of $4 \mathrm{hPa}$. High $\mathrm{OH}$ concentrations are produced by flash photolysis of ozone at $266 \mathrm{~nm}$ at a low frequency of 1 to $2 \mathrm{~Hz}$. The $\mathrm{OH}$ concentration is probed at a high frequency of $8.5 \mathrm{kHz}$ so that the loss of $\mathrm{OH}$ radicals due to their reaction with $\mathrm{OH}$ reactants in the ambient air can be observed.

with nitric oxide and by deposition processes. Therefore, a small flow of synthetic air $\left(0.2 \mathrm{~L} \mathrm{~min}^{-1}\right)$ that has passed an ozonizer (glass tube of fused silica with a mercury lamp providing $185 \mathrm{~nm}$ radiation) can be added in order to increase ozone mixing ratios in the flow tube by $40-50 \mathrm{ppbv}$. The injection is controlled by a solenoid valve which is automatically opened if the ozone mixing ratio in ambient air drops below 30 ppbv.

At a distance of $48 \mathrm{~cm}$ from the inlet of the flow tube, $1 \mathrm{~L} \mathrm{~min}^{-1}$ of the total flow is sampled from the center of the flow tube through a conical nozzle into the $\mathrm{OH}$ detection cell. The design of the $\mathrm{OH}$ fluorescence cell is the same as used for $\mathrm{OH}$ concentration measurements (Tan et al., 2017).

In the cell, $\mathrm{OH}$ is excited by $308 \mathrm{~nm}$ radiation from a tunable frequency-doubled dye laser, which is operated at a pulse repetition rate of $8.5 \mathrm{kHz}$. The $\mathrm{OH}$ fluorescence is detected by gated photon counting and accumulated in time bins of $0.6 \mathrm{~ms}$. This way, the chemical decay of $\mathrm{OH}$ in the flow tube is recorded for $1 \mathrm{~s}$ after the photolysis laser pulse. For photon detection, a gated multichannel photomultiplier (Photek, PM325) is used in combination with a multichannel counting card (Sigma Space, AMCS).

In order to achieve sufficiently precise reactivity measurements, 60 decay curves are taken for one reactivity measurement resulting in an amplitude of 50 to 100 counts of the decay curve. Because of the scanning of the laser over the absorption line of $\mathrm{OH}$ in order to track slow drifts in the wavelength of laser, the amplitude of the decay curve changes periodically. Therefore, $10 \mathrm{OH}$ decay curves are summed up to equalize the amplitude. Six of the summed curves are then averaged to determine realistic error estimates needed for the fit procedure. A weighted single-exponential fit (LevenbergMarquardt minimization) is then applied to derive the $\mathrm{OH}$ reactivity (Eq. 1). Approximately the first 30 to $50 \mathrm{~ms}$ of the decay curve are not included in the fit because these points deviate from the single-exponential behavior that is observed at later times. The fit is started if the count rate has decreased to the $90 \%$ level of the maximum count rate. The likely reason for an inhomogeneous initial $\mathrm{OH}$ distribution is that the spatial $\mathrm{OH}$ distribution is not perfectly homogeneous near the inlet nozzle of the $\mathrm{OH}$ detection cell right after the laser pulse due to inhomogeneities in the laser power across the laser beam.

Diffusion to the wall of the flow tube, where $\mathrm{OH}$ is lost by wall reactions, causes loss of $\mathrm{OH}$ even in the absence of $\mathrm{OH}$ reactant. This zero loss rate is regularly measured in humidified air (purity $99.999 \%$ ). Typical zero loss rates measured in laboratory characterization measurements are around $3 \mathrm{~s}^{-1}$ for this instrument. A slightly higher value of $3.8 \mathrm{~s}^{-1}$ was derived in measurements sampling synthetic air from a gas cylinder during the campaign. Analysis of the synthetic air in this gas cylinder by gas chromatography yielded contaminations with an $\mathrm{OH}$ reactivity of $0.7 \mathrm{~s}^{-1}$. Therefore, an instrumental zero decay value of $3.1 \mathrm{~s}^{-1}$ was subtracted from ambient $\mathrm{OH}$ reactivity measurements consistent with previous values for this instrument. The reactivity measured in the synthetic air is considered a potential systematic error of the $\mathrm{OH}$ reactivity measurements in this campaign. The accuracy of our LP-LIF technique has been tested with $\mathrm{CO}$ and $\mathrm{CH}_{4}$ mixtures in synthetic air. Measured $k_{\mathrm{OH}}$ agreed better than $10 \%$ with the expected, calculated $\mathrm{OH}$ reactivity for values up to $60 \mathrm{~s}^{-1}$, in agreement with previous studies by Lou et al. (2010). At higher $k_{\mathrm{OH}}$ values, the initial non-exponential part of the $\mathrm{OH}$ decay curve starts to influence the quality of the fitted $\mathrm{OH}$ decay curve, but such high $k_{\mathrm{OH}}$ values were not encountered in the campaign at Wangdu (Fig. 2).

Potential interferences that could be present in the $\mathrm{OH}$ concentration detection would not affect the measured $\mathrm{OH}$ 

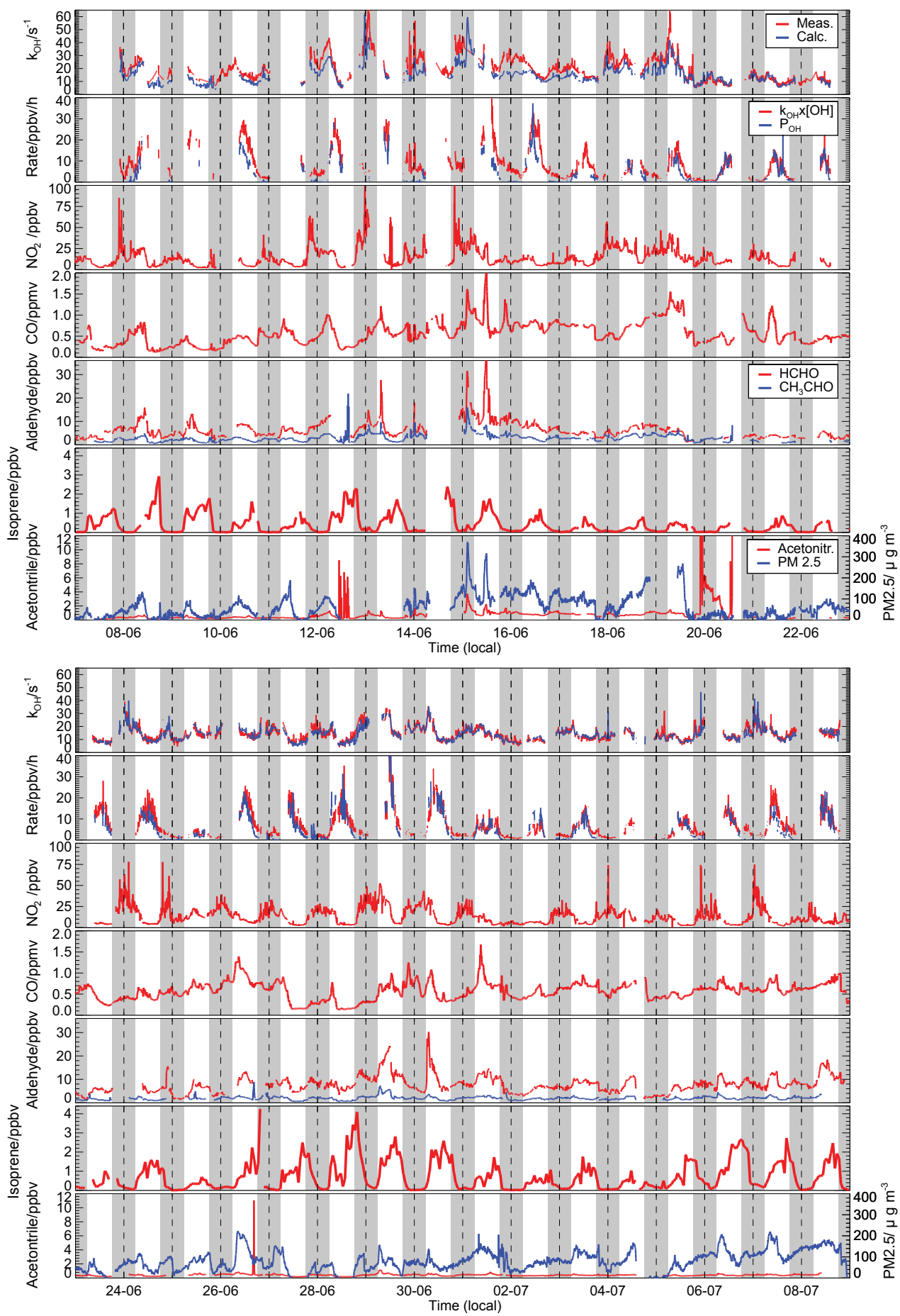

Figure 2. Time series of measured and calculated $\mathrm{OH}$ reactivity. In addition, time series of the $\mathrm{OH}$ destruction rate $\left(D_{\mathrm{OH}}\right)$ calculated from measured $\mathrm{OH}$ concentrations and $\mathrm{OH}$ reactivity is shown together with the sum of measured $\mathrm{OH}$ production rates $\left(P_{\mathrm{OH}}\right)$ from $\mathrm{O}_{3}$ and $\mathrm{HONO}$ photolysis and reactions of $\mathrm{HO}_{2}$ with $\mathrm{NO}$ and $\mathrm{O}_{3}$. Lower panels give time series of important trace gas measurements contributing to the $\mathrm{OH}$ reactivity. Gray areas indicate nighttime.

reactivity because $\mathrm{OH}$ that would be artificially produced inside the measurement cell would only increase the background signal but not the decay time as long as it do not change on the timescale of the $\mathrm{OH}$ decay measurement $(1 \mathrm{~s})$.
In any case, however, effects are expected to be negligible due to the high $\mathrm{OH}$ concentration inside the flow tube that are much higher compared to ambient $\mathrm{OH}$ concentrations, for which interferences have been recognized. This 
holds for the known interference from ozone photolysis by the $308 \mathrm{~nm}$ laser radiation but also for other potential interferences that have been reported for $\mathrm{OH}$ concentration measurements (Mao et al., 2012; Novelli et al., 2014) and which could not be fully excluded for this campaign (Tan et al., 2017).

If ambient $\mathrm{NO}$ concentrations are high enough to lead to a significant regeneration of $\mathrm{OH}$ from secondarily formed $\mathrm{HO}_{2}$, the shape of the decay curve changes to a biexponential behavior. This can be derived from reaction kinetics. The faster decay time represents approximately the $\mathrm{OH}$ reactivity for certain chemical conditions. As shown in Lou et al. (2010), no significant effects are expected for NO mixing ratios of up to $20 \mathrm{ppbv}$ for realistic $\mathrm{OH}$ reactant mixtures in our instrument. During the campaign in Wangdu, NO mixing ratios were generally well below 20 ppbv. No bi-exponential behavior was observed that would have been seen in the residuum of the fit. NO mixing ratios exceeded 20 ppbv only for some short periods mainly during the nighttime on 3 days, but measurements still appeared as singleexponential decays in these cases.

\section{Results and discussion}

\subsection{Time series of $\mathrm{OH}$ reactivity}

Measured $\mathrm{OH}$ reactivity values ranged between 10 and $20 \mathrm{~s}^{-1}$ during this campaign for most of the time (Fig. 2). In general, values were lower during the daytime (median value $12.4 \mathrm{~s}^{-1}$ ) than at night (median value $15.4 \mathrm{~s}^{-1}$ ). During the first 2 weeks, midday $\mathrm{OH}$ reactivity increased from $10 \mathrm{~s}^{-1}$ on 8 June to values higher than $20 \mathrm{~s}^{-1}$ between 15 and 19 June. After 19 June, $\mathrm{OH}$ reactivity was generally lower and more uniform till the end of the campaign.

Maximum values were observed during the nighttime and the early morning hours, when $\mathrm{OH}$ reactivities show spikes with values of up to $60 \mathrm{~s}^{-1}$ for short periods of less than $1 \mathrm{~h}$. The high-reactivity values were probably caused by emissions into the shallow nocturnal boundary layer. The short duration indicates that nearby local sources were responsible for these events. This happened more frequently during the first part of the campaign and only few spikes were observed after 19 June.

The overall changes in $\mathrm{OH}$ reactivity values from day to day were likely dominated by anthropogenic activities during this campaign. The measured $\mathrm{OH}$ reactivities show an increasing trend with $\mathrm{CO}$, which cannot be explained by the reactivity of $\mathrm{CO}$ alone (Fig. 3). Therefore, other reactants that were co-emitted with $\mathrm{CO}$, for example in combustion processes, most likely contributed to the increase in reactivity. The correlation still holds if only reactivity from measured $\mathrm{OH}$ reactants other than $\mathrm{CO}, \mathrm{NO}_{x}$ and isoprene is taken into account. This further supports that also $\mathrm{OH}$ reactivity from organic compounds is co-emitted with $\mathrm{CO}$.

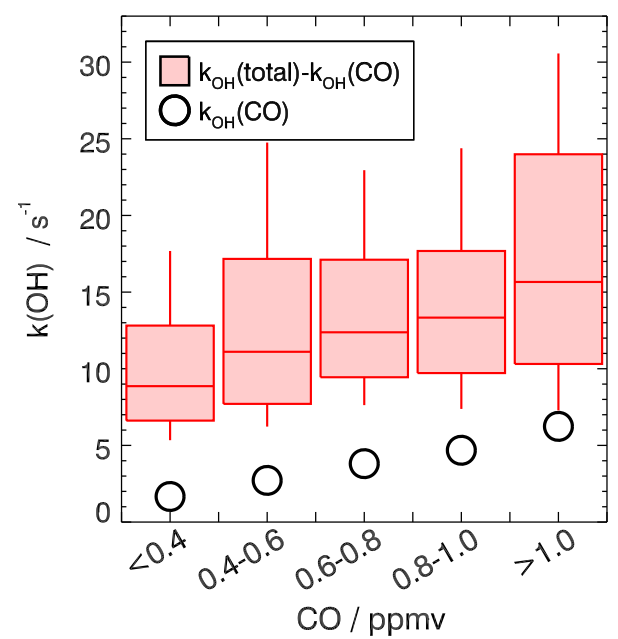

Figure 3. Correlation between $\mathrm{OH}$ reactivity excluding $\mathrm{CO}$ and $\mathrm{CO}$ mixing ratios. Red boxes give 25 and 75 percentiles, and whiskers give 10 and 90 percentiles of the $k_{\mathrm{OH}}$ distribution. Black circles show median values of $\mathrm{OH}$ reactivity that is caused by $\mathrm{CO}$.

Back-trajectories were calculated for this campaign using the NOAA (Nation Oceanic and Atmospheric Administration) HYSPLIT (Hybrid Single Particle Lagrangian Integrated Trajectory Model) model (Stein et al., 2015) in order to test if measured $\mathrm{OH}$ reactivities are correlated with the origin of advected air masses. Twenty-four hour backtrajectories were calculated for air masses at the measurement site for each hour. During most days, back-trajectories were very similar. Therefore, trajectories between 10:00 and 19:00 LT were averaged (Fig. 4). The majority of backtrajectories point to locations south of Wangdu and less often to locations east or north of the measurement site. Mountains that are west and north of the measurements site appear as barriers for air masses. Only on 3 days (8, 27, 28 June) back-trajectories indicate that air masses originated from locations in the mountains. Lowest $k_{\mathrm{OH}}$ values $\left(<10 \mathrm{~s}^{-1}\right)$ were observed in these cases due to less emissions from industry and from other anthropogenic activities. In contrast, there is dense population east and south of the measurements site. This likely explains why $\mathrm{OH}$ reactivity values were highest if air masses were coming from this area. Also, the relation between $k_{\mathrm{OH}}$ and $\mathrm{CO}$ is consistent with the assumption that $\mathrm{OH}$ reactivity was dominated by anthropogenic activities in this case.

The increase in $\mathrm{OH}$ reactivity during the first 2 weeks could be related to a change in the origin of air masses from the north ( 8 June) to the east (13 June) and finally to the south (15 June). However, no obvious difference between backtrajectories is seen before and after 20 June so that backtrajectories are not sufficient to explain why measured $\mathrm{OH}$ reactivity would be higher and spikier before 20 June.

The more likely reason for differences in $\mathrm{OH}$ reactivity is emissions connected with the harvesting of crop and combus- 


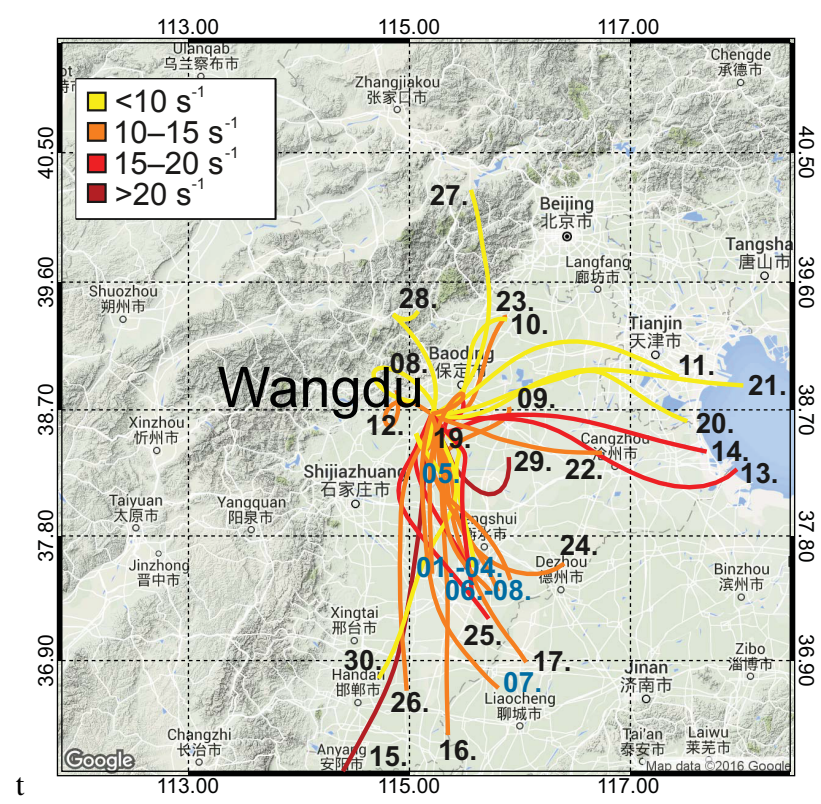

Figure 4. NOAA HYSPLIT $24 \mathrm{~h}$ back-trajectories during the campaign calculated as averages of hourly back-trajectories between 10:00 and 19:00 local time. Colors of trajectories indicate the $\mathrm{OH}$ reactivity level measured at the field site in Wangdu. Black numbers indicate the date in June, dark blue numbers the date in July.

tion of straw and crop residuals on nearby agricultural fields in the first 2 weeks of June. On 13 June, for example, crop was harvested on the field directly next to the measurement place. Indicators of biomass burning activities were visually observed fires, reduced visibility and an increase in measured particle number concentrations. Typical daytime maximum $\mathrm{PM}_{2.5}$ concentrations ranged between 30 and $90 \mu \mathrm{g} \mathrm{m}^{-3}$ but were as high as $300 \mathrm{\mu g} \mathrm{m}^{-3}$ on one day due to local biomass burning (Fig. 2). No clear connection between $\mathrm{OH}$ reactivity and aerosol number concentration was observed. Although a sharp drop in $\mathrm{PM}_{2.5}$ was observed on 19 June when $\mathrm{OH}$ reactivity also dropped, $\mathrm{PM}_{2.5}$ increased again to higher values till the end of the campaign. Elevated concentrations of acetonitrile (a marker for biomass combustion) were measured between 12 and 19 June (Tan et al., 2017).

\subsection{Contributions of $\mathrm{OH}$ reactants to the $\mathrm{OH}$ reactivity and missing reactivity}

$\mathrm{OH}$ reactivity measurements are of particular value in order to test if all important $\mathrm{OH}$ reactants were detected. Volatile organic compounds (VOCs) and inorganic compounds such as nitrogen oxides $\left(\mathrm{NO}_{x}=\mathrm{NO}+\mathrm{NO}_{2}\right)$ and carbon monoxide (CO) are typically major contributors to the total $\mathrm{OH}$ reactivity. However, the number of $\mathrm{OH}$ reactants, specifically of organic compounds is very large so that a complete measurement is not expected. Therefore, comparison of direct $k_{\mathrm{OH}}$ measurements with calculations from measured reactants can reveal to which extent unmeasured reactive com- pounds contributed to total $\mathrm{OH}$ reactivity. This presents a gap in the constraints of model calculations used to test our knowledge of radical chemistry (Tan et al., 2017). In addition, VOCs and $\mathrm{NO}_{x}$ are key species for understanding ozone and particle formation so that an incomplete knowledge of $\mathrm{OH}$ reactivity would lead to a systematic underprediction of ozone production by chemical models (e.g., Whalley et al., 2016; Griffith et al., 2016).

The full time series of the calculated $k_{\mathrm{OH}}$ is plotted together with the measured total $k_{\mathrm{OH}}$ in Fig. 2. The calculated reactivities were determined from measured $\mathrm{CO}, \mathrm{CH}_{4}$, $\mathrm{C}_{2}$ to $\mathrm{C}_{11}$ alkanes, $\mathrm{C}_{2}$ to $\mathrm{C}_{6}$ alkenes, $\mathrm{C}_{6}$ to $\mathrm{C}_{10}$ aromatics, formaldehyde, glyoxal, acetaldehyde, MVK, MACR, NO, $\mathrm{NO}_{2}$ and $\mathrm{SO}_{2}$ (Table 1). Reaction rate constants were taken from IUPAC recommendations (Atkinson et al., 2004, 2006) or the structure-activity relationship (SAR) as stated in the Master Chemical Model (http://mcm.leeds.ac.uk/MCM/).

During each of the two parts of the campaign (before and after 19 June), diurnal profiles of observations appear to be similar. Therefore, measured $k_{\mathrm{OH}}$ and calculated reactivity from major contributors are shown as median diurnal profiles with percentiles for each period in Fig. 5. Median diurnal profiles of all measured contributions are summed up and compared to measured $k_{\mathrm{OH}}$ in Fig. 6. Ambient temperature was used for the calculation of reaction rate constants, but the differences between ambient temperature and the actual temperature in the instrument does not change any of the results shown here.

The most important $\mathrm{OH}$ reactants were $\mathrm{CO}$ (on average 20 to $25 \%$ of the total $\mathrm{OH}$ reactivity), nitrogen oxides (on average 12 to $22 \%$ of the total OH reactivity) and OVOCs (on average $25 \%$ of the total $\mathrm{OH}$ reactivity). The reactivity from isoprene makes a substantial contribution (often 20\%) to the total $k_{\mathrm{OH}}$ in the afternoon. Reactivity from alkanes and alkenes were dominated by small alkenes, mostly ethene and propene.

The median diurnal profile of the total $\mathrm{OH}$ reactivity had a maximum late at night. It decreased during the day by nearly $50 \%$ and started to increase after sunset. The accumulation of $\mathrm{OH}$ reactants during the night could be due to fresh emissions that are released into the shallow nocturnal boundary layer. A similar diurnal profile was also observed for contributions from $\mathrm{NO}_{x}$, alkane and alkene species. Their concentrations are typically connected to emissions from anthropogenic activities. $\mathrm{OH}$ reactivity from $\mathrm{NO}_{x}$ was also the largest contribution to $k_{\mathrm{OH}}$ during night and early morning (20 to $30 \%$ ). The diurnal profile of $\mathrm{NO}_{x}$ appears as the major driver for the diurnal profile of the entire $k_{\mathrm{OH}}$, whereas nearly all other contributions exhibited a less distinct diurnal profile. A different diurnal behavior to that of $\mathrm{NO}_{x}$ was observed for isoprene, which is emitted by plants. The emission strength scales with light and temperature, and, therefore, maximum mixing ratios were reached in the afternoon. Isoprene also contributed to the reactivity in the early evening, most likely because isoprene that was emitted during the daytime was 

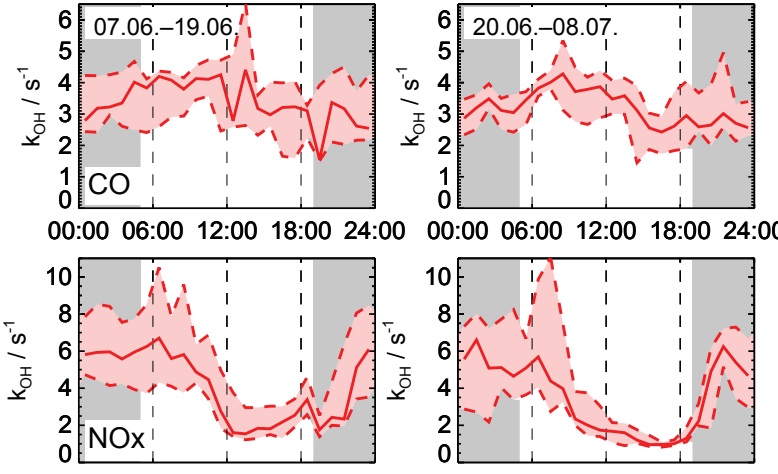

00:00 06:00 12:00 18:00 24:00

00:00 06:00 12:00 18:00 24:00
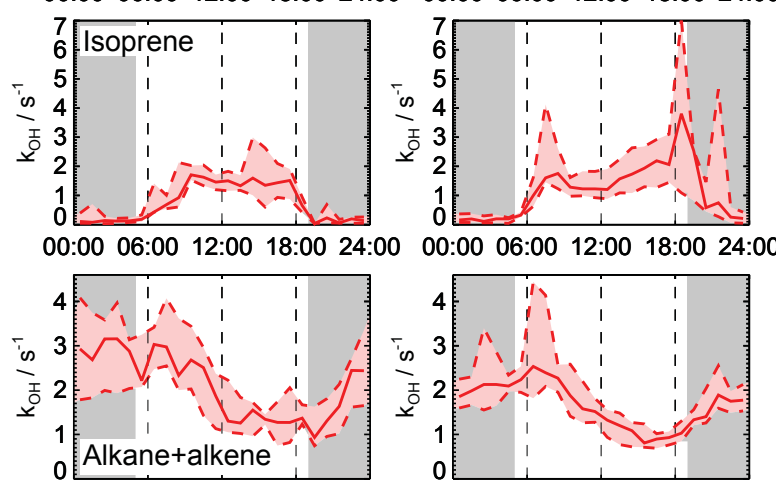

00:00 06:00 12:00 18:00 24:00
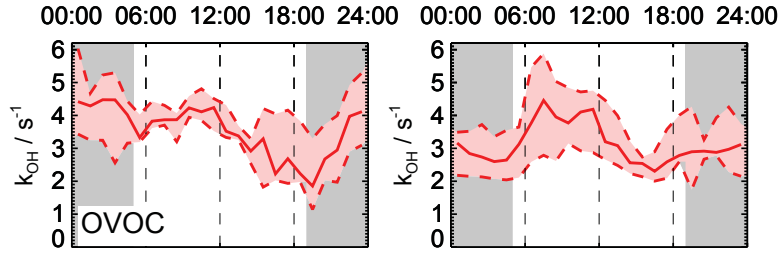

00:00 06:00 12:00 18:00 24:00
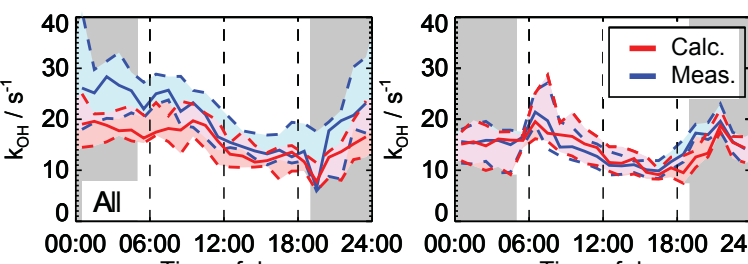

Time of day
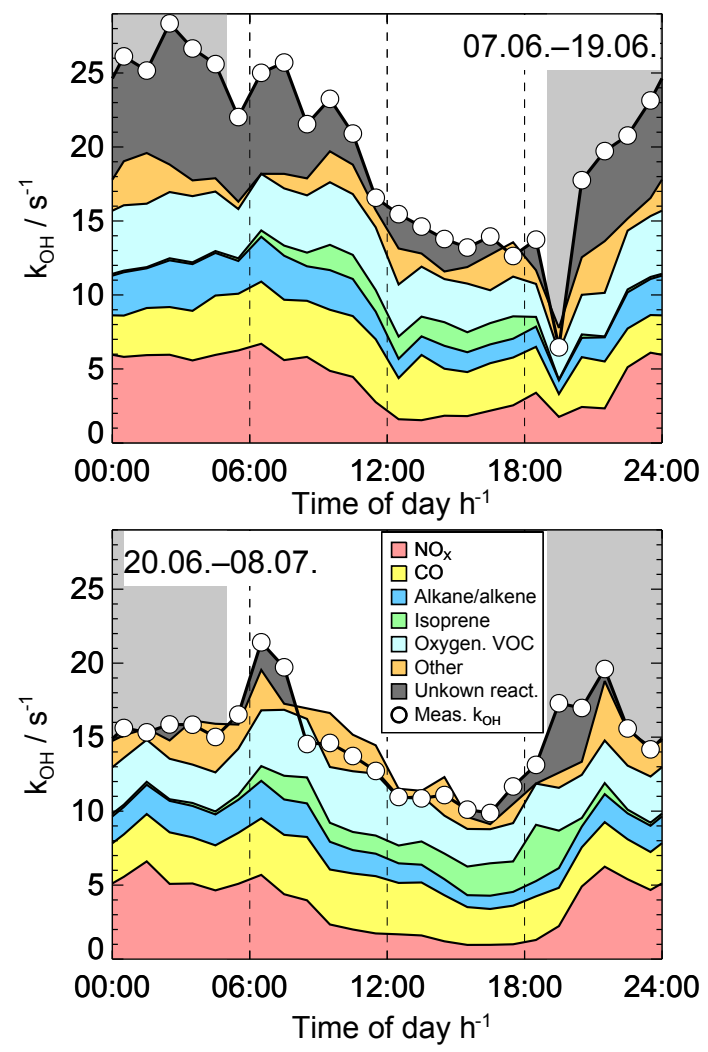

Figure 6. Sum of median diurnal profiles of reactivities from all measured $\mathrm{OH}$ reactants compared to the measured $\mathrm{OH}$ reactivity for the first and second part of the campaign. Data are only included if all major $\mathrm{OH}$ reactants and $\mathrm{OH}$ reactivity were measured concurrently. "Other" includes small contributions from measured $\mathrm{OH}$ reactants listed in Table $1\left(\mathrm{CH}_{4}, \mathrm{SO}_{2}\right.$, aromatics). The dark gray area indicates missing $\mathrm{OH}$ reactivity from unmeasured $\mathrm{OH}$ reactants. Light gray areas indicate nighttime.

changes. As discussed above, measured $k_{\mathrm{OH}}$ scaled with $\mathrm{CO}$ indicating that co-emitted $\mathrm{OH}$ reactants such as alkenes were also important (Fig. 3).

A number of oxygenated volatile organic compounds (OVOCs) were measured in this campaign (Table 1). These included formaldehyde, acetaldehyde, glyoxal, methyl-vinyl ketone and methacrolein. Their reactivity made a large fraction of the total reactivity with median values between 2 and $4 \mathrm{~s}^{-1}$ over the course of 1 day. The largest contributions to the reactivity from OVOCs (more than 50\%) came from formaldehyde and acetaldehyde (20 to $25 \%$ ), while reactivity from other measured OVOCs such as acetone and glyoxal made only small contributions. These species can also originate from primary emissions. The good agreement between measured and calculated $\mathrm{OH}$ reactivity nevertheless indicates that these species were the most important organic oxidation products that contributed to the $\mathrm{OH}$ reactivity.

The reactivity of measured OVOCs shows weak diurnal variation, with a decrease by a factor of about 2 from the 


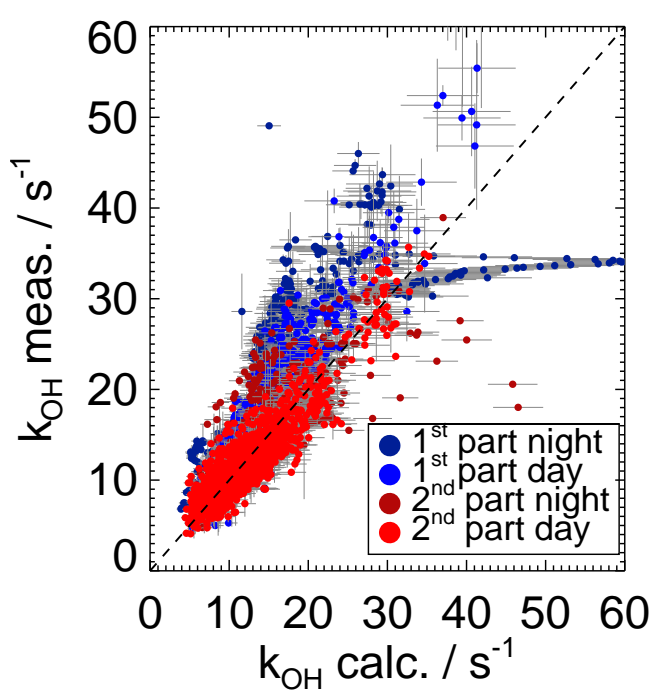

Figure 7. Correlation between calculated and measured $\mathrm{OH}$ reactivity with color-coded periods. The linear correlation coefficient $\left(R^{2}\right)$ is 0.77 for the entire data set and data from both periods alone.

morning to the evening. This behavior suggests that during the daytime, dilution due to a rising boundary layer height or chemical removal had a stronger influence on the observed OVOCs than fresh production by photochemistry.

Although the general behavior of $\mathrm{OH}$ reactivity and $\mathrm{OH}$ reactants was similar during the entire campaign, there were distinct differences in the magnitude of total $\mathrm{OH}$ reactivity during the first ( 7 to 19 June) and second half (20 June to 8 July) of the campaign (Fig. 5). Measured $\mathrm{OH}$ reactivity was on average lower after 20 June specifically during the second half of the night and early morning, when median values were higher than $25 \mathrm{~s}^{-1}$ before 20 June and 16 to $20 \mathrm{~s}^{-1}$ later. Afternoon values were only slightly less after 20 June compared to the first part of the campaign. This is reflected in a decrease in median $\mathrm{OH}$ reactant concentrations during the second part of the campaign. It is most prominently seen in median alkene and alkane concentrations during the nighttime (Fig. 5). In contrast, isoprene concentrations increased faster in the morning and high afternoon concentrations persisted in the evening during the second part of the campaign. Air temperatures were generally a few degrees higher than during the first 2 weeks so that temperature-driven biogenic emissions could have been larger after 20 June. The largest fraction of higher $\mathrm{OH}$ reactivity observed in the first part of the campaign remains unexplained by $\mathrm{OH}$ reactant measurements. However, even during times when measured reactivity was higher than calculations from $\mathrm{OH}$ reactants, the gap is within the combined $2 \sigma$ uncertainties: the $k_{\mathrm{OH}}$ calculated from $\mathrm{OH}$ reactants has a $1 \sigma$ uncertainty of \pm 10 to $\pm 15 \%$, depending on the relative distributions of reactants, and the measured $k_{\mathrm{OH}}$ has a maximum $1 \sigma$ uncertainty of $\pm 10 \%$ plus $+0.7 \mathrm{~s}^{-1}$ (Table 1).
The good agreement between measured and calculated $\mathrm{OH}$ reactivity is also demonstrated by the high linear correlation coefficient $\left(R^{2}=0.77\right.$ for the entire data set and both subsets of data) between both values (Fig. 7). For the second part of the campaign, a linear regression analysis (forced to zero) yields a slope of 1.01. As already discussed, missing reactivity was higher during the first part of the campaign so that a regression analysis yields a higher slope of 1.3.

Largest differences of 5 to $6 \mathrm{~s}^{-1}$ (approximately $20 \%$ ) between measured and calculated $\mathrm{OH}$ reactivity occurred during the nighttime and early morning during the first 2 weeks of the campaign, when NO concentrations were also highest. This could indicate that unmeasured $\mathrm{OH}$ reactants were co-emitted with nitrogen oxides in combustion processes. Unknown compounds causing the missing reactivity are the main reason for the higher observed $\mathrm{OH}$ reactivity in the first 2 weeks. Therefore, there is no clear further indication of the nature of missing reactivity during this period. Emissions of organic compounds from biomass burning may have not been detected during the first part of the campaign. During the nighttime nearby sources for $\mathrm{OH}$ reactants as indicated by the short duration of high reactivity could also have contributed to the missing reactivity. In addition, undetected products from the oxidation by the nitrate radical could have been part of missing reactivity in the night.

Exceptionally good agreement is seen at nearly all times after 20 June in the time series as well as in the median diurnal profile (Figs. 2 and 6). The median value of missing reactivity is only $0.3 \mathrm{~s}^{-1}$. Such good agreement is not expected due to the large number of possible $\mathrm{OH}$ reactants in the atmosphere (Goldstein and Galbally, 2007). Specifically the number of OVOCs that were measured in this campaign is rather small (see above) and additional reactivity from other oxidation products could be expected to contribute to the total $\mathrm{OH}$ reactivity.

The good agreement between measured and calculated $k_{\mathrm{OH}}$ indicates that other oxidation products than those measured were not significantly contributing to the $\mathrm{OH}$ reactivity at the measurement site. Therefore, concentrations of oxygenated organic compounds that are produced by model calculations but that were not detected were constrained to zero in calculations presented in our accompanying paper by Tan et al. (2017) in order to ensure that modeled $\mathrm{OH}$ reactivity is consistent with measurements. One explanation could be that the photochemical age of air masses was short and, therefore, oxidation products could not accumulate. This could be the case for fresh emissions close to the measurement site. In addition, unmeasured oxidation products may still have contributed to the $\mathrm{OH}$ reactivity within the combined uncertainties of $\mathrm{OH}$ reactivity measurements and calculations from $\mathrm{OH}$ reactant measurements. 


\subsection{Comparison with previous field campaigns}

In our previous field campaigns in China in 2006 in the Pearl River delta (PRD; Hofzumahaus et al., 2009; Lou et al., 2010; Lu et al., 2012) and Yufa close to Beijing (Lu et al., 2013), OH reactivity was considerably higher, but exhibited a similar diurnal profile. Maximum values were 40 to $50 \mathrm{~s}^{-1}$ in the night and early morning during the PRD and Yufa campaigns and reached minimum values of around $20 \mathrm{~s}^{-1}$ in the afternoon. Absolute contributions from $\mathrm{CO}$ and $\mathrm{NO}_{x}$ were comparable with contributions in Wangdu 2014, with slightly higher CO concentrations in Yufa 2006. However, contributions from measured VOC were significantly higher in both previous campaigns compared to the Wangdu campaign in 2014, partly explaining the higher reactivity in these campaigns.

In both previous campaigns, measurements of OVOCs were completely missing and the measured $\mathrm{OH}$ reactivity was found to be about 2 times larger than the total reactivity of measured $\mathrm{CO}, \mathrm{NO}_{x}$ and hydrocarbons (Lou et al., 2010). The missing reactivity could be quantitatively explained by OVOCs which were simulated by a model from the photooxidation of the measured VOCs. The major modeled OVOCs were formaldehyde, acetaldehyde, MVK, MACR and some minor isoprene oxidation products, which together could explain $70 \%$ of the missing reactivity (i.e., about one-third of the total reactivity). In the Wangdu campaign, the calculated total $\mathrm{OH}$ reactivity was largely in agreement with the measured $k_{\mathrm{OH}}$. This time, formaldehyde, acetaldehyde, MVK, MACR and glyoxal were directly measured and also accounted for one-third of the total reactivity. These species were also the most important OVOC species in other campaigns in anthropogenically dominated environments such as in Beijing (Shao et al., 2009), London (Whalley et al., 2016) and Tokyo (Yoshino et al., 2012). This confirms the high relevance of these specific carbonyl compounds as reactants for $\mathrm{OH}$ in the polluted boundary layer.

The $\mathrm{OH}$ reactivities measured at the Wangdu site in the North China Plain show diurnal profiles that are comparable to those reported for other polluted environments all over the world (see review by Yang et al., 2016). The total reactivities lie within the range of values observed during summertime at other locations that were mainly influenced by anthropogenic emissions, like Nashville (Kovacs et al., 2003), New York (Ren et al., 2003) and Houston (Mao et al., 2010) in the US, Tokyo in Japan (Chatani et al., 2009), Beijing (Williams et al., 2016) in China, Seoul in South Korea (Kim et al., 2016), and London (Whalley et al., 2016) in Great Britain. Also, the shapes of the diurnal profiles were similar, with peak values between 15 and $50 \mathrm{~s}^{-1}$ in the early morning and minimum values in the afternoon. Significantly higher morning values of $130 \mathrm{~s}^{-1}$ were observed in Mexico City in 2003 (Shirley et al., 2006). Here, as well as in Wangdu and other urban sites, the diurnal shape of $k_{\mathrm{OH}}$ was strongly determined by the variation in anthropogenically emitted $\mathrm{NO}_{x}$ and coemitted VOCs.

Care has to be taken if missing reactivity is compared between different campaigns because the number of measured $\mathrm{OH}$ reactants used to calculate the reactivity can significantly differ (Lou et al., 2010; Yang et al., 2016, and references therein). For the measurements in Beijing (Williams et al., 2016), approximately $25 \%$ of the measured reactivity remained unexplained, although oxygenated organic species were partly measured. Approximately $30 \%$ of the reactivity measured in Nashville could not be explained, even if modeled organic compounds were taken into account. For the other campaigns in anthropogenically influenced areas, measured $\mathrm{OH}$ reactivity could be explained by either measured $\mathrm{OH}$ reactants alone (New York, this campaign) or if, in addition, product species from model calculations were included (Yufa, PRD, Tokyo, London).

\subsection{Experimental OH budget}

$\mathrm{OH}$ reactivity measurements can be used not only to quantify the possible contribution of unmeasured $\mathrm{OH}$ reactants, but they also allow the quantification of the total $\mathrm{OH}$ production rate. Because $\mathrm{OH}$ is short-lived, it reaches a steady state within seconds. Thus, the total $\mathrm{OH}$ production rate $\left(P_{\mathrm{OH}}\right)$ equals the total destruction rate $\left(D_{\mathrm{OH}}\right) . D_{\mathrm{OH}}$ can be calculated as the product of $k_{\mathrm{OH}}$ and the $\mathrm{OH}$ concentration:

$D_{\mathrm{OH}}=k_{\mathrm{OH}} \times[\mathrm{OH}]$.

This rate can be compared with the sum of production rates $\left(P_{\mathrm{OH}}\right)$ from known $\mathrm{OH}$ sources. In this campaign, $\mathrm{OH}$ production from $\mathrm{HONO}$ and $\mathrm{O}_{3}$ photolysis, ozonolysis of alkenes, and radical recycling reactions of $\mathrm{HO}_{2}$ with $\mathrm{NO}$ and ozone can be calculated from measurements:

$$
\begin{aligned}
P_{\mathrm{OH}}= & P_{\mathrm{OH}}\left(h v+\mathrm{O}_{3}\right)+P_{\mathrm{OH}}(h v+\mathrm{HONO})+P_{\mathrm{OH}}\left(\mathrm{HO}_{2}+\mathrm{O}_{3}\right) \\
& +P_{\mathrm{OH}}\left(\mathrm{HO}_{2}+\mathrm{NO}\right)+P_{\mathrm{OH}}\left(\mathrm{O}_{3}+\text { alkene }\right) .
\end{aligned}
$$

Potentially unknown $\mathrm{OH}$ sources can then be determined as the difference between $D_{\mathrm{OH}}$ and $P_{\mathrm{OH}}$. This was successfully applied for data from our previous field campaigns in China (Hofzumahaus et al., 2009), revealing significant unaccounted $\mathrm{OH}$ sources, and in chamber studies (Fuchs et al., 2013, 2014; Nehr et al., 2014).

The time series of calculated $\mathrm{OH}$ production and destruction rates are plotted in Fig. 2, and median diurnal profiles of quantities that are required for this calculation are shown in Fig. 8. Unfortunately, the data coverage of simultaneous measurements before 20 June (mostly due to missing radical measurements) is not sufficient to allow for an independent analysis of the first part of the campaign as done for the analysis of $\mathrm{OH}$ reactants. However, results do not change significantly, whether the first part is included in the median diurnal profiles that are discussed below or not.

Figure 9 shows the median diurnal profile of the $\mathrm{OH}$ destruction and production rates and their difference, including 

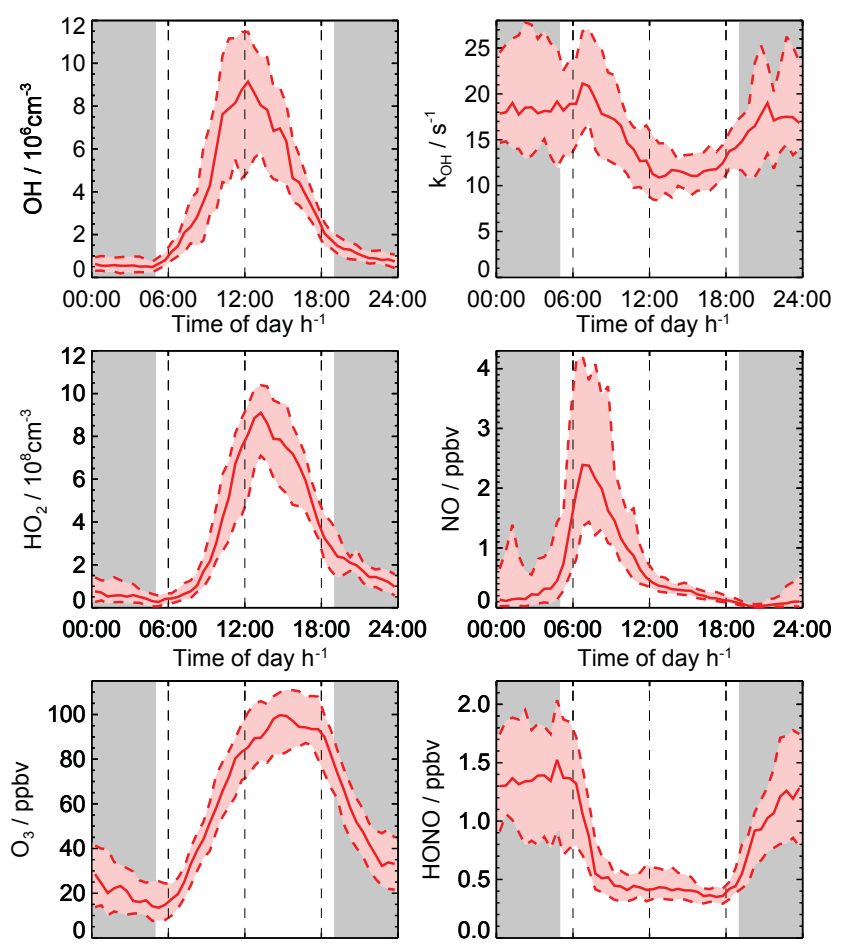

00:00 $\quad 06: 00 \quad 12: 00 \quad 18: 00 \quad 24: 00$
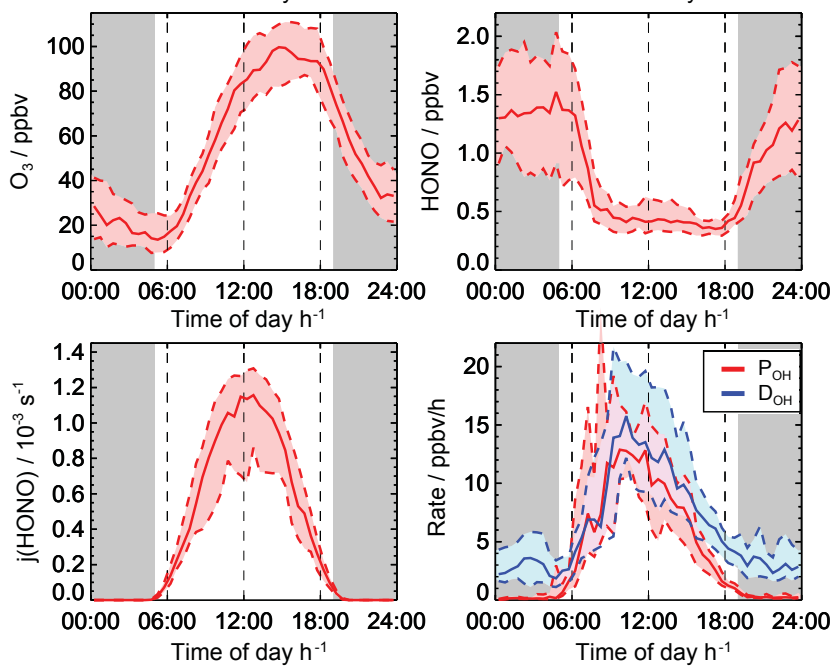

Figure 8. Median diurnal profiles of trace gas concentrations used for the calculation of the total $\mathrm{OH}$ production rate $\left(P_{\mathrm{OH}}\right)$ and destruction rate $\left(D_{\mathrm{OH}}\right)$. Data are only included if all required trace gas concentrations and $\mathrm{OH}$ reactivity were measured concurrently. Colored areas give 25 and 75 percentiles. Gray areas indicate nighttime. Note that the selection of data are different for median profiles shown in our accompanying paper by Tan et al. (2017).

an estimate of the accuracy of the calculated difference. The diurnal profile of the $\mathrm{OH}$ production rate was mainly driven by solar radiation as expected from the photolytic nature of primary radical production, which also determines the overall abundance of $\mathrm{HO}_{2}$. During the daytime, the known $\mathrm{OH}$ production was dominated by the recycling reaction of $\mathrm{HO}_{2}$ with $\mathrm{NO}$, reaching a maximum of about $10 \mathrm{ppbv} \mathrm{h}^{-1}$ shortly before noon. The relative contribution of primary $\mathrm{OH}$ production by either $\mathrm{O}_{3}$ or HONO photolysis to the total $\mathrm{OH}$ production increased during the day to reach median maximum values of 1.2 and $1.5 \mathrm{ppbh}^{-1}$, respectively. The ozone photolysis exhibited a strong diurnal profile because both solar radiation and ozone concentration had maximum values

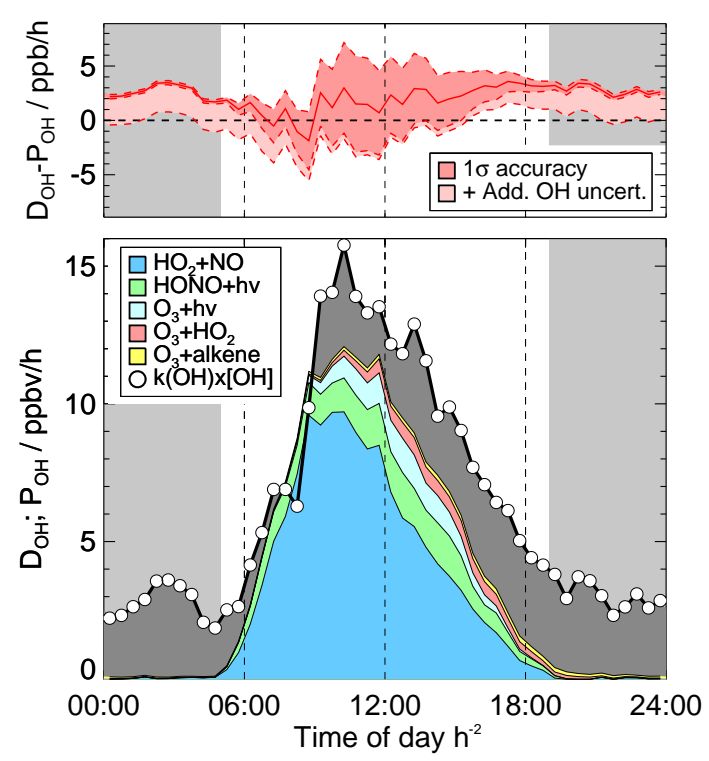

Figure 9. Median diurnal profiles of $\mathrm{OH}$ production $\left(P_{\mathrm{OH}}\right)$ and destruction $\left(D_{\mathrm{OH}}\right)$ rates. Data are only included if all required trace gas concentrations and $\mathrm{OH}$ reactivity were measured concurrently. Dark gray areas indicate missing $\mathrm{OH}$ production. The upper panel gives the $1 \sigma$ accuracy of the difference $\left(D_{\mathrm{OH}}-P_{\mathrm{OH}}\right)$ calculated from the uncertainties of measurements (Gaussian error propagation). The effect on the accuracy from an upper limit of potential interferences in the $\mathrm{OH}$ measurements is shown separately.

at noon and in the early afternoon. An $\mathrm{OH}$ production rate from HONO photolysis of 1 to $1.5 \mathrm{ppbh}^{-1}$ persisted into the afternoon due to relatively high HONO concentrations measured throughout the day. The budget of HONO will be discussed in a separate paper, but it is clear that HONO production from the reaction of $\mathrm{OH}$ with $\mathrm{NO}$ cannot explain the high HONO concentrations in the afternoon. Ozonolysis of alkene species made only a minor contribution to the $\mathrm{OH}$ production at all times. Only $\mathrm{C}_{2}$ to $\mathrm{C}_{6}$ alkene species were measured so that ozonolysis reactions of undetected alkene species (potentially monoterpenes) could have additionally contributed to the $\mathrm{OH}$ production. However, the good agreement between measured and calculated $\mathrm{OH}$ reactivity does not indicate that a large fraction of alkene species were missed.

The time series of the total $\mathrm{OH}$ production and destruction rates, determined by Eqs. (2) and (3), respectively, were nearly balanced for most of the time (Fig. 2). The $\mathrm{OH}$ destruction rate is on average only $20 \%$ higher than the sum of $\mathrm{OH}$ production during the daytime. Although the difference is hardly significant with respect to the experimental accuracies (Fig. 9), a systematic trend of the ratio between $\mathrm{OH}$ production and destruction rates with $\mathrm{NO}$ can be seen (Fig. 10), which points to a missing $\mathrm{OH}$ source at low NO concentrations.

For NO mixing ratios of less than 0.3 ppbv, $\mathrm{OH}$ destruction was nearly twice as large as the $\mathrm{OH}$ production, whereas pro- 


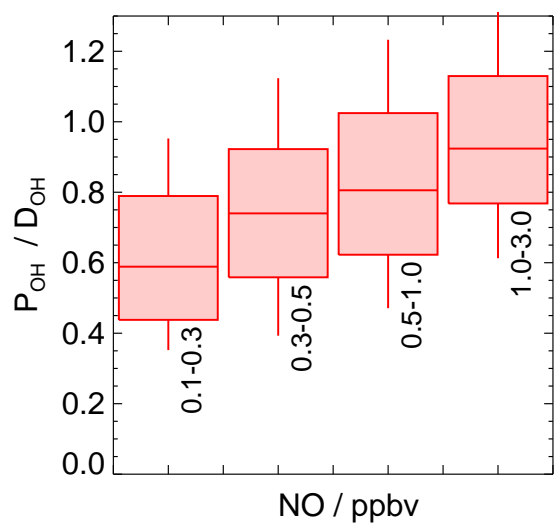

Figure 10. Box and whisker plot of the ratio of the total $\mathrm{OH}$ production $\left(P_{\mathrm{OH}}\right)$ and the $\mathrm{OH}$ destruction rate $\left(D_{\mathrm{OH}}\right)$ as a function of the NO mixing ratio for daytime values. Boxes give 25 and 75 percentiles, and whiskers give 10 and 90 percentiles. Data are only included if all required trace gas concentrations and $\mathrm{OH}$ reactivity were measured concurrently. Gray areas indicate nighttime.

duction and destruction was balanced for NO mixing ratios higher than $1 \mathrm{ppbv}$. The result of the budget analysis is consistent with the finding by Tan et al. (2017) that model calculations underpredict $\mathrm{OH}$ by up to a factor of 2 at $\mathrm{NO}$ mixing ratios of less than $0.3 \mathrm{ppbv}$ but describe $\mathrm{HO}_{2}$ and $k_{\mathrm{OH}}$ correctly under these conditions at the Wangdu site. The good description of $\mathrm{HO}_{2}$ and $k_{\mathrm{OH}}$ means that the major known $\mathrm{OH}$ source (the reaction of $\mathrm{HO}_{2}$ and $\mathrm{NO}$ ) and the total $\mathrm{OH}$ loss rate are represented well by the model. Further model tests suggest a missing process that recycles $\mathrm{OH}$ from $\mathrm{RO}_{2}$ and $\mathrm{HO}_{2}$ by an unknown agent that behaves like $0.1 \mathrm{ppbv} \mathrm{NO}$ (Tan et al., 2017). Other trace gases measured at Wangdu give no indication as to the nature of the missing source in the $\mathrm{OH}$ budget analysis or in the model results. A similar behavior was found in our previous field campaigns in China in 2006. However, the ratio of $P_{\mathrm{OH}} / D_{\mathrm{OH}}$ was much smaller, with a value of about 0.25 for NO mixing ratios of 0.1 to 0.2 ppbv NO in PRD (Hofzumahaus et al., 2009). In this case, the missing $\mathrm{OH}$ source was highly significant with respect to the experimental uncertainties of the calculated reaction rates, whereas in Wangdu, the much weaker imbalance of the $\mathrm{OH}$ budget can be almost explained by the experimental errors.

In addition to the measurement uncertainties stated in Table 1 , instrumental tests during this campaign cannot exclude that $\mathrm{OH}$ concentration measurements are partly affected by an artifact, as discussed in detail in Tan et al. (2017). The upper limit for an instrumental interference was estimated to be equivalent to an $\mathrm{OH}$ concentration of $1 \times 10^{6} \mathrm{~cm}^{-3}$. This positive bias would also give a positive bias in the calculated $\mathrm{OH}$ destruction rate.

In the night, $\mathrm{OH}$ production from sources taken into account in this calculation is close to zero because there is no radiation. This suppresses both $\mathrm{OH}$ production from photol- ysis reactions and $\mathrm{OH}$ regeneration by the reaction of peroxy radicals with $\mathrm{NO}$. Because of the relatively high $\mathrm{OH}$ reactivity $\mathrm{OH}$ concentrations are expected to be very small. However, median measured $\mathrm{OH}$ concentrations ranged between 0.5 and $1 \times 10^{6} \mathrm{~cm}^{-3}$ (Fig. 8). A median $\mathrm{OH}$ production of 1 to $3 \mathrm{ppbvh}^{-1}$ would be required to explain measured nighttime $\mathrm{OH}$ concentrations (Fig. 9).

Potential reasons for additional $\mathrm{OH}$ production at night have been recently discussed by Lu et al. (2014), such as $\mathrm{OH}$ production by ozonolysis of terpenoids or dissociation of radical reservoir species like PAN that may be transported downward in the nocturnal boundary layer. Such mechanisms may have played a role at Wangdu, but we have no suitable measured data to test these hypotheses. In order to balance the calculated $\mathrm{OH}$ destruction rate during the nighttime, a rather large concentration of an alkene would be required. Assuming an ozone concentration of $30 \mathrm{ppbv}$, a reaction rate constant for the ozonolysis reaction of $1.8 \times 10^{-15} \mathrm{~cm}^{3} \mathrm{~s}^{-1}$ for $\delta$-terpene and an $\mathrm{OH}$ yield of 1 (Atkinson and Arey, 2003), the concentration would need to be around 600 pptv.

However, the impact of a potential interference in the $\mathrm{OH}$ concentration measurements would also be largest in the night (Fig. 9) because nearly the entire $\mathrm{OH}$ signal could be due to interferences. As a consequence, the difference between calculated $\mathrm{OH}$ production and destruction during the nighttime is within this additional uncertainty. The calculated $\mathrm{OH}$ destruction rate is less affected during the daytime, when a potential $\mathrm{OH}$ interference of less than $1 \times 10^{6} \mathrm{~cm}^{-3}$ would only be a small fraction of the total measured $\mathrm{OH}$ (Tan et al., 2017).

In our previous field campaigns in China in 2006, the $\mathrm{OH}$ destruction and production rates were significantly higher than in this campaign. In PRD and Yufa, maximum mean turnover rates $\left(\mathrm{OH}\right.$ destruction rates) of 40 and $20 \mathrm{ppbv} \mathrm{h}^{-1}$, respectively, were reached around noontime (Lu et al., 2012, 2013). These values are 1.5 to 3 times higher than median $\mathrm{OH}$ turnover rates in this campaign. As discussed above, the major difference is that measured $\mathrm{OH}$ reactivities were significantly higher in the previous campaigns. The resulting higher loss rate was only partly balanced by a higher $\mathrm{OH}$ production from the reaction of $\mathrm{HO}_{2}$ with $\mathrm{NO}$, which was nearly a factor of 2 larger in PRD and Yufa. Therefore, the gap between calculated $\mathrm{OH}$ destruction and production was also clearly above the level of significance with respect to the measurement uncertainties (Hofzumahaus et al., 2009).

Also, the distribution of primary $\mathrm{OH}$ sources is different in this campaign compared to our previous campaigns in China, when HONO photolysis exhibited a diurnal profile with maximum values in the morning. These values were larger compared to this campaign, but HONO mixing ratios dropped to lower values in the afternoon so that production by HONO photolysis was less in Yufa and PRD than in Wangdu in 2016. Nevertheless, total primary $\mathrm{OH}$ production was higher (by a factor of 2 in PRD and a factor of 1.5 in Yufa) in the previous campaigns. 
HONO photolysis was also the most important primary source for $\mathrm{OH}$ radicals in other campaigns that were conducted in anthropogenically dominated environments for example in New York (Ren et al., 2003), Paris (Michoud et al., 2012), Mexico City (Dusanter et al., 2009), Santiago (Elshorbany et al., 2009) and Tokyo (Kanaya et al., 2007). These campaigns took place in or very close to very large cities (the one in Paris during wintertime) and NO concentrations were often exceptionally high so that HONO formation was favored. Our measurement site in Wangdu was not directly located in an urban area, and therefore the $\mathrm{NO}_{x}$ concentrations were only moderately high in the morning and rather small in the afternoon so that the importance of $\mathrm{HONO}$ as the largest primary source for $\mathrm{OH}$ was not necessarily expected. The contribution of alkene ozonolysis to the $\mathrm{OH}$ production in other campaigns in urban environments was partly significantly higher (Kanaya et al., 2007; Dusanter et al., 2009; Elshorbany et al., 2009) compared to the Wangdu site due to higher alkene concentrations.

\section{Summary and conclusions}

$\mathrm{OH}$ reactivity was measured during a comprehensive field campaign at Wangdu in summer 2014. Additional measurements of $\mathrm{OH}$ reactants, $\mathrm{OH}$ concentrations and quantities that are required to calculate $\mathrm{OH}$ production $\left(\mathrm{HO}_{2}, \mathrm{NO}, \mathrm{O}_{3}\right.$, $\mathrm{HONO}$, photolysis frequencies) allowed comparing $\mathrm{OH}$ reactivity measurements with calculations from measured $\mathrm{OH}$ reactants and analyzing the chemical $\mathrm{OH}$ budget from measurements alone.

Overall, measured $\mathrm{OH}$ reactivity can mostly be explained by $\mathrm{OH}$ reactant measurements, specifically during the second half of the campaign. Highest missing reactivity of the median diurnal profile (approximately $25 \%$ ) was observed during the nighttime of the first part of the campaign, which could have been related to nearby emissions or undetected oxidation products. The diurnal profile of $\mathrm{OH}$ reactivity, the distribution of $\mathrm{OH}$ reactant and the good correlation of the $\mathrm{OH}$ reactivity with $\mathrm{CO}$ indicates that the chemical composition at the measurement site was mainly impacted by anthropogenic emissions. In our previous field campaigns in China in 2006, the number of $\mathrm{OH}$ reactants that were measured was less, and, thus, only approximately $50 \%$ of the measured $\mathrm{OH}$ reactivity was explained by measured $\mathrm{OH}$ reactants (Lou et al., 2010; Lu et al., 2012, 2013). However, additional OH reactants determined by model calculations could close the gap in these cases. In this campaign, the good agreement between measured and calculated reactivity indicates that most important organic compounds were measured, including oxidation products.

$\mathrm{OH}$ production and destruction were mainly balanced within the uncertainty of measurements. The accuracy of this calculation was lowered by additional uncertainty in the $\mathrm{OH}$ concentration measurements due to a potential bias (Tan et al., 2017). Despite this uncertainty, the $\mathrm{OH}$ destruction tends to be higher than $\mathrm{OH}$ production in the late afternoon, when NO concentrations were lowest. This result is consistent with the analysis of model calculations (Tan et al., 2017) and findings in previous field campaigns (Hofzumahaus et al., 2009).

However, in 2006 the observed discrepancy between the $\mathrm{OH}$ production and destruction rates was significantly larger requiring an additional $\mathrm{OH}$ source to close the gap. The major difference to this campaign was that the measured $\mathrm{OH}$ reactivity was much higher. Therefore, a significant gap in $\mathrm{OH}$ production and destruction rates was found, in contrast to results in this campaign. For future field work, comprehensive studies like this campaign in photochemically active environments where larger contributions from biogenic reactants can be expected in addition to anthropogenic emissions may help to solve the still open questions of imbalances in $\mathrm{OH}$ production and destruction and measured and calculated $\mathrm{OH}$ reactivity that have been observed in other campaigns.

\section{Data availability}

The data of this paper are available upon request. Please contact the corresponding authors Yuanhang Zhang (yhzhang@pku.edu.cn) or Hendrik Fuchs (h.fuchs@fzjuelich.de).

Acknowledgement. We thank the science teams of the Wangdu2014 campaign. This work was supported by the National Natural Science Foundation of China (Major Program: 21190052 and Innovative Research Group: 41121004), the Strategic Priority Research Program of the Chinese Academy of Sciences (grant no. XDB05010500), the Collaborative Innovation Center for Regional Environmental Quality and the EU-project AMIS (Fate and Impact of Atmospheric Pollutants, PIRSES-GA-2011-295132). The authors gratefully acknowledge the NOAA Air Resources Laboratory (ARL) for the provision of the HYSPLIT transport and dispersion model and READY website (http://www.ready.noaa.gov) used in this publication.

Edited by: D. Parrish

Reviewed by: four anonymous referees

\section{References}

Atkinson, R. and Arey, J.: Gas-phase tropospheric chemistry of biogenic volatile organic compounds: a review, Atmos. Environ., 37, S197-S219, doi:10.1016/S1352-2310(03)00391-1, 2003.

Atkinson, R., Baulch, D. L., Cox, R. A., Crowley, J. N., Hampson, R. F., Hynes, R. G., Jenkin, M. E., Rossi, M. J., and Troe, J.: Evaluated kinetic and photochemical data for atmospheric chemistry: Volume $\mathrm{I}-$ gas phase reactions of $\mathrm{O}_{x}, \mathrm{HO}_{x}, \mathrm{NO}_{x}$ and $\mathrm{SO}_{x}$ species, Atmos. Chem. Phys., 4, 1461-1738, doi:10.5194/acp-41461-2004, 2004. 
Atkinson, R., Baulch, D. L., Cox, R. A., Crowley, J. N., Hampson, R. F., Hynes, R. G., Jenkin, M. E., Rossi, M. J., Troe, J., and IUPAC Subcommittee: Evaluated kinetic and photochemical data for atmospheric chemistry: Volume II - gas phase reactions of organic species, Atmos. Chem. Phys., 6, 3625-4055, doi:10.5194/acp-6-3625-2006, 2006.

Bohn, B., Corlett, G. K., Gillmann, M., Sanghavi, S., Stange, G., Tensing, E., Vrekoussis, M., Bloss, W. J., Clapp, L. J., Kortner, M., Dorn, H.-P., Monks, P. S., Platt, U., Plass-Dülmer, C., Mihalopoulos, N., Heard, D. E., Clemitshaw, K. C., Meixner, F. X., Prevot, A. S. H., and Schmitt, R.: Photolysis frequency measurement techniques: results of a comparison within the ACCENT project, Atmos. Chem. Phys., 8, 5373-5391, doi:10.5194/acp-85373-2008, 2008.

Chatani, S., Shimo, N., Matsunaga, S., Kajii, Y., Kato, S., Nakashima, Y., Miyazaki, K., Ishii, K., and Ueno, H.: Sensitivity analyses of $\mathrm{OH}$ missing sinks over Tokyo metropolitan area in the summer of 2007, Atmos. Chem. Phys., 9, 8975-8986, doi:10.5194/acp-9-8975-2009, 2009.

Dong, H.-B., Zeng, L.-M., Hu, M., Wu, Y.-S., Zhang, Y.-H., Slanina, J., Zheng, M., Wang, Z.-F., and Jansen, R.: Technical Note: The application of an improved gas and aerosol collector for ambient air pollutants in China, Atmos. Chem. Phys., 12, 1051910533, doi:10.5194/acp-12-10519-2012, 2012.

Dusanter, S., Vimal, D., Stevens, P. S., Volkamer, R., Molina, L. T., Baker, A., Meinardi, S., Blake, D., Sheehy, P., Merten, A., Zhang, R., Zheng, J., Fortner, E. C., Junkermann, W., Dubey, M., Rahn, T., Eichinger, B., Lewandowski, P., Prueger, J., and Holder, H.: Measurements of $\mathrm{OH}$ and $\mathrm{HO}_{2}$ concentrations during the MCMA-2006 field campaign - Part 2: Model comparison and radical budget, Atmos. Chem. Phys., 9, 6655-6675, doi:10.5194/acp-9-6655-2009, 2009.

Ehhalt, D. H.: Photooxidation of trace gases in the troposphere, Phys. Chem. Chem. Phys., 1, 5401-5408, doi:10.1039/a905097c, 1999.

Elshorbany, Y. F., Kurtenbach, R., Wiesen, P., Lissi, E., Rubio, M., Villena, G., Gramsch, E., Rickard, A. R., Pilling, M. J., and Kleffmann, J.: Oxidation capacity of the city air of Santiago, Chile, Atmos. Chem. Phys., 9, 2257-2273, doi:10.5194/acp-92257-2009, 2009.

Fuchs, H., Bohn, B., Hofzumahaus, A., Holland, F., Lu, K. D., Nehr, S., Rohrer, F., and Wahner, A.: Detection of $\mathrm{HO}_{2}$ by laserinduced fluorescence: calibration and interferences from $\mathrm{RO}_{2}$ radicals, Atmos. Meas. Tech., 4, 1209-1225, doi:10.5194/amt4-1209-2011, 2011.

Fuchs, H., Hofzumahaus, A., Rohrer, F., Bohn, B., Brauers, T., Dorn, H.-P., Häseler, R., Holland, F., Kaminski, M., Li, X., Lu, K., Nehr, S., Tillmann, R., Wegener, R., and Wahner, A.: Experimental evidence for efficient hydroxyl radical regeneration in isoprene oxidation, Nat. Geosci., 6, 1023-1026, doi:10.1038/NGEO1964, 2013.

Fuchs, H., Acir, I.-H., Bohn, B., Brauers, T., Dorn, H.-P., Häseler, R., Hofzumahaus, A., Holland, F., Kaminski, M., Li, X., Lu, K., Lutz, A., Nehr, S., Rohrer, F., Tillmann, R., Wegener, R., and Wahner, A.: $\mathrm{OH}$ regeneration from methacrolein oxidation investigated in the atmosphere simulation chamber SAPHIR, Atmos. Chem. Phys., 14, 7895-7908, doi:10.5194/acp-14-78952014, 2014.
Goldstein, A. H. and Galbally, I. E.: Known and unexplored organic constituents in the earth's atmosphere, Environ. Sci. Technol., 41, 1514-1521, doi:10.1021/es072476p, 2007.

Griffith, S. M., Hansen, R. F., Dusanter, S., Michoud, V., Gilman, J. B., Kuster, W. C., Veres, P. R., Graus, M., de Gouw, J. A., Roberts, J., Young, C., Washenfelder, R., Brown, S. S., Thalman, R., Waxman, E., Volkamer, R., Tsai, C., Stutz, J., Flynn, J. H., Grossberg, N., Lefer, B., Alvarez, S. L., Rappenglueck, B., Mielke, L. H., Osthoff, H. D., and Stevens, P. S.: Measurements of hydroxyl and hydroperoxy radicals during CalNex-LA: Model comparisons and radical budgets, J. Geophys. Res., 121, 42114232, doi:10.1002/2015JD024358, 2016.

Hofzumahaus, A., Rohrer, F., Lu, K., Bohn, B., Brauers, T., Chang, C.-C., Fuchs, H., Holland, F., Kita, K., Kondo, Y., Li, X., Lou, S., Shao, M., Zeng, L., Wahner, A., and Zhang, Y.: Amplified trace gas removal in the troposphere, Science, 324, 1702-1704, doi:10.1126/science.1164566, 2009.

Holland, F., Hofzumahaus, A., Schäfer, J., Kraus, A., and Pätz, H. W.: Measurements of $\mathrm{OH}$ and $\mathrm{HO}_{2}$ radical concentrations and photolysis frequencies during BERLIOZ, J. Geophys. Res., 108, 8246, doi:10.1029/2001JD001393, 2003.

Kanaya, Y., Cao, R., Akimoto, H., Fukuda, M., Komazaki, Y., Yokouchi, Y., Koike, M., Tanimoto, H., Takegawa, N., and Kondo, Y.: Urban photochemistry in central Tokyo: 1. observed and modeled $\mathrm{OH}$ and $\mathrm{HO}_{2}$ radical concentrations during the winter and summer 2004, J. Geophys. Res., 112, D21312, doi:10.1029/2007JD008670, 2007.

Kim, S., Sanchez, D., Wang, M., Seco, R., Jeong, D., Hughes, S., Barletta, B., Blake, D. R., Jung, J., Kim, D., Lee, G., Lee, M., Ahn, J., Lee, S.-D., Cho, G., Sung, M.-Y., Lee, Y.H., Kim, D. B., Kim, Y., Woo, J.-H., Jo, D., Park, R., Park, J.-H., Hong, Y.-D., and Hong, J.-H.: OH reactivity in urban and suburban regions in Seoul, South Korea - an East Asian megacity in a rapid transition, Faraday Discuss., 189, 231-251, doi:10.1039/C5FD00230C, 2016.

Kovacs, T. A., Brune, W. H., Harder, H., Martinez, M., Simpas, J. B., Frost, G. J., Williams, E., Jobson, T., Stroud, C., Young, V., Fried, A., and Wert, B.: Direct measurements of urban $\mathrm{OH}$ reactivity during Nashville SOS in summer 1999, J. Environ. Monitor., 5, 68-74, doi:10.1039/B204339D, 2003.

Li, X., Rohrer, F., Hofzumahaus, A., Brauers, T., Häseler, R., Bohn, B., Broch, S., Fuchs, H., Gomm, S., Holland, F., Jäger, J., Kaiser, J., Keutsch, F. N., Lohse, I., Lu, K., Tillmann, R., Wegener, R., Wolfe, G. M., Mentel, T. F., Kiendler-Scharr, A., and Wahner, A.: Missing gas-phase source of HONO inferred from Zeppelin measurements in the troposphere, Science, 344, 292-296, doi:10.1126/science.1248999, 2014.

Liu, Y., Lu, K., Dong, H., Li, X., Cheng, P., Zou, Q., Wu, Y., Liu, X., and Zhang, Y.: In situ monitoring of atmospheric nitrous acid based on multi-pumping flow system and liquid waveguide capillary cell, J. Environ. Sci., 43, 273-284, doi:10.1016/j.jes.2015.11.034, 2016.

Lou, S., Holland, F., Rohrer, F., Lu, K., Bohn, B., Brauers, T., Chang, C. C., Fuchs, H., Häseler, R., Kita, K., Kondo, Y., Li, X., Shao, M., Zeng, L., Wahner, A., Zhang, Y., Wang, W., and Hofzumahaus, A.: Atmospheric $\mathrm{OH}$ reactivities in the Pearl River Delta - China in summer 2006: measurement and model results, Atmos. Chem. Phys., 10, 11243-11260, doi:10.5194/acp-10-11243-2010, 2010. 
Lu, K., Zhang, Y., Su, H., Brauers, T., Chou, C. C., Hofzumahaus, A., Liu, S. C., Kita, K., Kondo, Y., Shao, M., Wahner, A., Wang, J., Wang, X., and Zhu, T.: Oxidant $\left(\mathrm{O}_{3}+\mathrm{NO}_{2}\right)$ production processes and formation regimes in Beijing, J. Geophys. Res., 115, D07303, doi:10.1029/2009JD012714, 2010.

Lu, K. D., Rohrer, F., Holland, F., Fuchs, H., Bohn, B., Brauers, T., Chang, C. C., Häseler, R., Hu, M., Kita, K., Kondo, Y., Li, X., Lou, S. R., Nehr, S., Shao, M., Zeng, L. M., Wahner, A., Zhang, Y. H., and Hofzumahaus, A.: Observation and modelling of $\mathrm{OH}$ and $\mathrm{HO}_{2}$ concentrations in the Pearl River Delta 2006: a missing $\mathrm{OH}$ source in a VOC rich atmosphere, Atmos. Chem. Phys., 12, 1541-1569, doi:10.5194/acp-12-1541-2012, 20

Lu, K. D., Hofzumahaus, A., Holland, F., Bohn, B., Brauers, T., Fuchs, H., Hu, M., Häseler, R., Kita, K., Kondo, Y., Li, X., Lou, S. R., Oebel, A., Shao, M., Zeng, L. M., Wahner, A., Zhu, T., Zhang, Y. H., and Rohrer, F.: Missing $\mathrm{OH}$ source in a suburban environment near Beijing: observed and modelled $\mathrm{OH}$ and $\mathrm{HO}_{2}$ concentrations in summer 2006, Atmos. Chem. Phys., 13, 10571080, doi:10.5194/acp-13-1057-2013, 2013.

Lu, K. D., Rohrer, F., Holland, F., Fuchs, H., Brauers, T., Oebel, A., Dlugi, R., Hu, M., Li, X., Lou, S. R., Shao, M., Zhu, T., Wahner, A., Zhang, Y. H., and Hofzumahaus, A.: Nighttime observation and chemistry of $\mathrm{HO}_{x}$ in the Pearl River Delta and Beijing in summer 2006, Atmos. Chem. Phys., 14, 4979-4999, doi:10.5194/acp-14-4979-2014, 2014.

Mao, J., Ren, X., Chen, S., Brune, W. H., Chen, Z., Martinez, M., Harder, H., Lefer, B., Rappenglück, B., Flynn, J., and Leuchner, M.: Atmospheric oxidation capacity in the summer of Houston 2006: Comparison with summer measurements in other metropolitan studies, Atmos. Environ., 44, 4107-4115, doi:10.1016/j.atmosenv.2009.01.013, 2010.

Mao, J., Ren, X., Zhang, L., Van Duin, D. M., Cohen, R. C., Park, J.-H., Goldstein, A. H., Paulot, F., Beaver, M. R., Crounse, J. D., Wennberg, P. O., DiGangi, J. P., Henry, S. B., Keutsch, F. N., Park, C., Schade, G. W., Wolfe, G. M., Thornton, J. A., and Brune, W. H.: Insights into hydroxyl measurements and atmospheric oxidation in a California forest, Atmos. Chem. Phys., 12, 8009-8020, doi:10.5194/acp-12-8009-2012, 2012.

Michoud, V., Kukui, A., Camredon, M., Colomb, A., Borbon, A., Miet, K., Aumont, B., Beekmann, M., Durand-Jolibois, R., Perrier, S., Zapf, P., Siour, G., Ait-Helal, W., Locoge, N., Sauvage, S., Afif, C., Gros, V., Furger, M., Ancellet, G., and Doussin, J. F.: Radical budget analysis in a suburban European site during the MEGAPOLI summer field campaign, Atmos. Chem. Phys., 12, 11951-11974, doi:10.5194/acp-12-11951-2012, 2012.

Min, K.-E., Washenfelder, R. A., Dubé, W. P., Langford, A. O., Edwards, P. M., Zarzana, K. J., Stutz, J., Lu, K., Rohrer, F., Zhang, Y., and Brown, S. S.: A broadband cavity enhanced absorption spectrometer for aircraft measurements of glyoxal, methylglyoxal, nitrous acid, nitrogen dioxide, and water vapor, Atmos. Meas. Tech., 9, 423-440, doi:10.5194/amt-9-423-2016, 2016.

Nehr, S., Bohn, B., Dorn, H.-P., Fuchs, H., Häseler, R., Hofzumahaus, A., Li, X., Rohrer, F., Tillmann, R., and Wahner, A.: Atmospheric photochemistry of aromatic hydrocarbons: $\mathrm{OH}$ budgets during SAPHIR chamber experiments, Atmos. Chem. Phys., 14, 6941-6952, doi:10.5194/acp-14-6941-2014, 2014.

Novelli, A., Hens, K., Tatum Ernest, C., Kubistin, D., Regelin, E., Elste, T., Plass-Dülmer, C., Martinez, M., Lelieveld, J., and Harder, H.: Characterisation of an inlet pre-injector laser- induced fluorescence instrument for the measurement of atmospheric hydroxyl radicals, Atmos. Meas. Tech., 7, 3413-3430, doi:10.5194/amt-7-3413-2014, 2014.

Parker, A. E., Amedro, D., Schoemaecker, C., and Fittschen, C.: OH radical reactivity measurements by FAGE, Environ. Eng. Manag. J., 10, 107-114, 2011.

Ren, X., Harder, H., Martinez, M., Lesher, R. L., Oliger, A., Shirley, T., Adams, J., Simpas, J. B., and Brune, W. H.: $\mathrm{HO}_{X}$ concentrations and $\mathrm{OH}$ reactivity observations in New York City during PMTACS-NY2001, Atmos. Environ., 37, 3627-3637, 2003.

Rohrer, F., Lu, K., Hofzumahaus, A., Bohn, B., Brauers, T., Chang, C.-C., Fuchs, H., Haseler, R., Holland, F., Hu, M., Kita, K., Kondo, Y., Li, X., Lou, S., Oebel, A., Shao, M., Zeng, L., Zhu, T., Zhang, Y., and Wahner, A.: Maximum efficiency in the hydroxylradical-based self-cleansing of the troposphere, Nat. Geosci., 7, 559-563, doi:10.1038/ngeo2199, 2014.

Sadanaga, Y., Yoshino, A., Watanaba, K., Yoshioka, A., Wakazono, Y., Kanaya, Y., and Kajii, Y.: Development of a measurement system of peroxy radicals using a chemical amplification/laserinduced fluorescence technique, Rev. Sci. Instrum., 75, 864-872, doi:10.1063/1.1666985, 2004.

Shao, M., Lu, S., Liu, Y., Xie, X., Chang, C., Huang, S., and Chen, Z.: Volatile organic compounds measured in summer in Beijing and their role in ground-level ozone formation, J. Geophys. Res., 114, D00G06, doi:10.1029/2008JD010863, 2009.

Shirley, T. R., Brune, W. H., Ren, X., Mao, J., Lesher, R., Cardenas, B., Volkamer, R., Molina, L. T., Molina, M. J., Lamb, B., Velasco, E., Jobson, T., and Alexander, M.: Atmospheric oxidation in the Mexico City Metropolitan Area (MCMA) during April 2003, Atmos. Chem. Phys., 6, 2753-2765, doi:10.5194/acp-62753-2006, 2006.

Stein, A. F., Draxler, R. R., Rolph, G. D., Stunder, B. J. B., Cohen, M. D., and Ngan, F.: NOAAś HYSPLIT atmospheric transport and dispersion modeling system, B. Am. Meteorol. Soc., 96, 2059-2077, doi:10.1175/BAMS-D-14-00110.1, 2015.

Stone, D., Whalley, L. K., Ingham, T., Edwards, P. M., Cryer, D. R., Brumby, C. A., Seakins, P. W., and Heard, D. E.: Measurement of $\mathrm{OH}$ reactivity by laser flash photolysis coupled with laser-induced fluorescence spectroscopy, Atmos. Meas. Tech., 9, 2827-2844, doi:10.5194/amt-9-2827-2016, 2016.

Tan, Z., Fuchs, H., Lu, K., Hofzumahaus, A., Bohn, B., Broch, S., Dong, H., Gomm, S., Häseler, R., He, L., Holland, F., Li, X., Liu, Y., Lu, S., Rohrer, F., Shao, M., Wang, B., Wang, M., Wu, Y., Zeng, L., Zhang, Y., Wahner, A., and Zhang, Y.: Radical chemistry at a rural site (Wangdu) in the North China Plain: observation and model calculations of $\mathrm{OH}$, $\mathrm{HO}_{2}$ and $\mathrm{RO}_{2}$ radicals, Atmos. Chem. Phys., 17, 663-690, doi:10.5194/acp-17-663-2017, 2017.

Wang, M., Zeng, L., Lu, S., Shao, M., Liu, X., Yu, X., Chen, W., Yuan, B., Zhang, Q., Hu, M., and Zhang, Z.: Development and validation of a cryogen-free automatic gas chromatograph system (GC-MS/FID) for online measurements of volatile organic compounds, Analytical Methods, 6, 9424-9434, doi:10.1039/C4AY01855A, 2014.

Whalley, L. K., Stone, D., Bandy, B., Dunmore, R., Hamilton, J. F., Hopkins, J., Lee, J. D., Lewis, A. C., and Heard, D. E.: Atmospheric $\mathrm{OH}$ reactivity in central London: observations, model predictions and estimates of in situ ozone production, Atmos. 
Chem. Phys., 16, 2109-2122, doi:10.5194/acp-16-2109-2016, 2016.

Williams, J., Kessel, S. U., Nolscher, A. C., Yang, Y., Lee, Y., Yanez-Serrano, A. M., Wolff, S., Kesselmeier, J., Klupfel, T., Lelieveld, J., and Shao, M.: Opposite $\mathrm{OH}$ reactivity and ozone cycles in the Amazon rainforest and megacity Beijing: Subversion of biospheric oxidant control by anthropogenic emissions, Atmos. Environ., 125, Part A, 112-118, doi:10.1016/j.atmosenv.2015.11.007, 2016.

Yang, Y., Shao, M., Wang, X., Nölscher, A. C., Kessel, S., Guenther, A., and Williams, J.: Towards a quantitative understanding of total OH reactivity: A review, Atmos. Environ., 134, 147-161, doi:10.1016/j.atmosenv.2016.03.010, 2016.
Yoshino, A., Nakashima, Y., Miyazaki, K., Kato, S., Suthawaree, J., Shimo, N., Matsunaga, S., Chatani, S., Apel, E., Greenberg, J., Guenther, A., Ueno, H., Sasaki, H., Hoshi, J.-Y., Yokota, H., Ishii, K., and Kajii, Y.: Air quality diagnosis from comprehensive observations of total $\mathrm{OH}$ reactivity and reactive trace species in urban central Tokyo, Atmos. Environ., 49, 51-59, doi:10.1016/j.atmosenv.2011.12.029, 2012. 